No $2009-37$

December

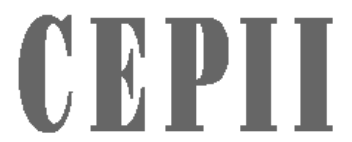

CENTE

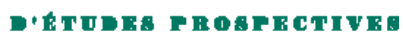

ET D'INOEMATIONS

INTEENATIONALE:

Assessing Barriers to Trade in the Distribution and Telecom sectors in Emerging Countries

Lionel Fontagné \& Cristina Mitaritonna 


\section{TABLE OF CONTENTS}

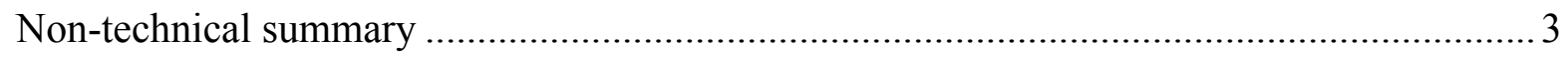

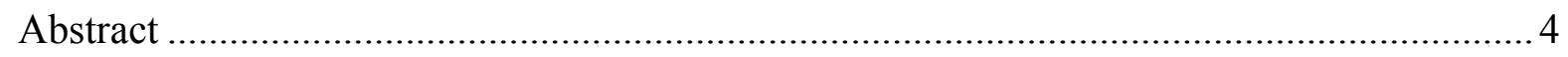

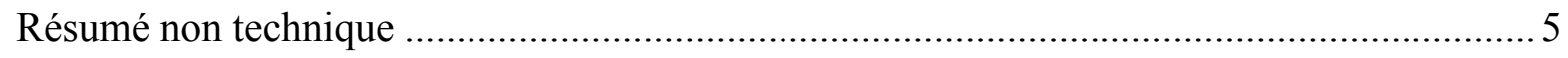

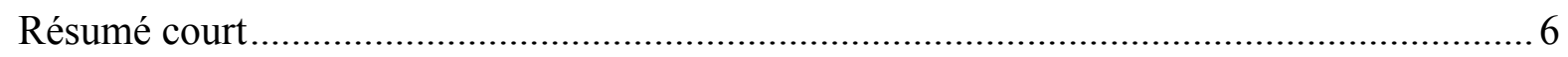

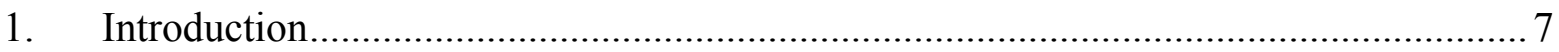

2. Methodology to Construct Syntethic Trade Restrictiveness Indexes ........................... 9

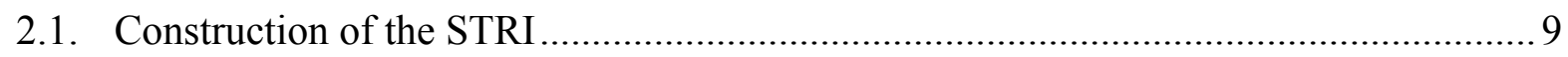

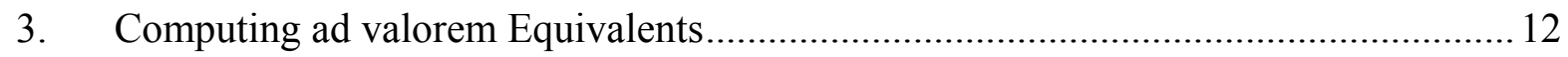

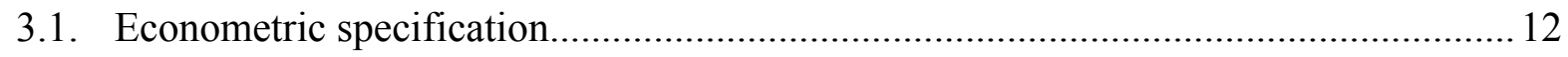

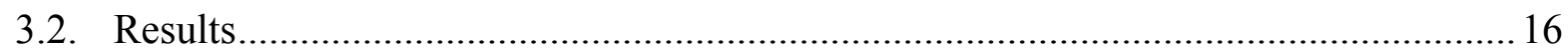

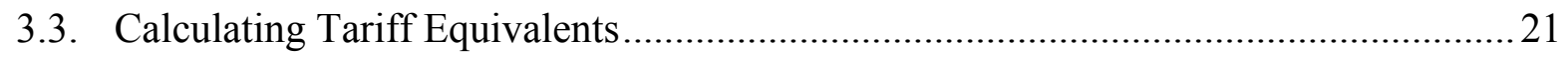

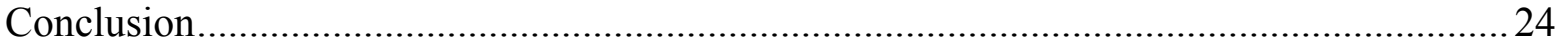

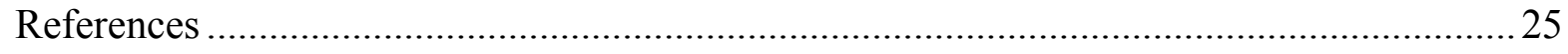

Appendix A: Components of the Restrictiveness Indices .................................................26

Appendix B: Sector Datasets Used for Regressions ..................................................... 32

Appendix C: Additional results for Regressions ............................................................. 35

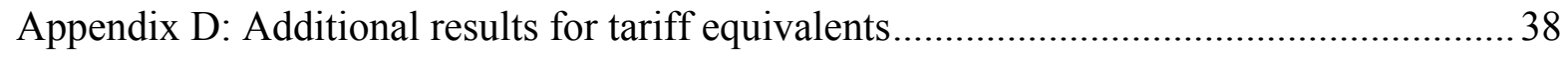

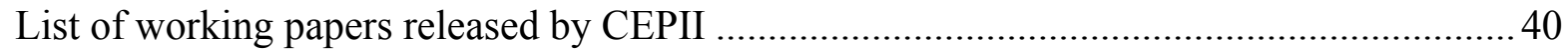




\section{ASSESSING BARRIERS TO TRADE IN THE DISTRIBUTION AND TELECOM SECTORS IN EMERGING COUNTRIES}

\section{NON-TECHNICAL SUMMARY}

This paper improves the way ad valorem equivalents (AVEs) for the regulation in service sectors can be computed on the basis of qualitative information. Three services sectors (i.e. fixed telecom, mobile telecom, distribution) are chosen and the method is applied on a group of emerging countries. Our source of information is the questionnaire responses provided by the Queen Mary University. We start with qualitative information on the restrictions applied by each country in each sector on the basis of which we applied a multivariate statistical approach, PCA, to transform this qualitative data into a synthetic trade restrictiveness index (STRI).

We extracted as much information as possible from the original data, based on a statistical criterion, weighting the different components based on their contribution to the whole variance. The next stage consists in regressing individual firms price cost margins on this STRI and control variables. In order to perform the regressions we need enough variance in the data, which requires a larger sample of countries by sector than our sample of 11 emerging economies. To this purpose we rely on data provided by Dihel and Sheperd (2007). A new and parsimonious econometric method is used which provides consistent and significant parameter estimates. It is shown that the STRI has a significant effect on the pricecost margins of the individual firms only when controlled for Regional trade Agreements and exception to the MFN clause in the considered sector.

The estimated parameters are finally used to compute AVEs, by applying them to the STRI computed from the treatment of the questionnaire responses. More than half our AVEs are larger than $50 \%$ and one AVE out of six is above $100 \%$.

The value added of our work is threefold. We provide a series of new tariff equivalents, based on precise estimates; a coding structure to guide future qualitative studies; and propose technical improvements to the estimation of restrictiveness indices and their impact on price cost margins. 


\begin{abstract}
We compute ad valorem equivalents (AVEs) for the regulation in three service sectors (i.e. fixed telecom, mobile telecom, distribution) applied by selected emerging countries. We start with qualitative information on the restrictions applied by each country in each sector on the basis of which we apply a multivariate statistical approach, to transform this qualitative data into a trade restrictiveness synthetic index (STRI). In a second stage we estimate the average impact of STRI on price cost margins, using a method avoiding the usual two-stage estimation. In the third stage, this impact is used to calculate the AVE of the STRI estimated in the first step. It is shown that the STRI has a significant effect on the price-cost margins of the individual firms only when controlled for Regional trade Agreements and exception to the MFN clause in the considered sector. Lastly, we compute tariff equivalents for the STRIs previously calculated using the estimated impact. More than half our AVEs are larger than $50 \%$ and one AVE out of six is above $100 \%$.
\end{abstract}

JEL Classification: F13

Key Words: $\quad$ Services; ad valorem equivalents 


\section{BARRIÈRES À L'ENTRÉE DANS LE SECTEUR DISTRIBUTION ET TELECOM D'UN AUTRE PAYS ÉMERGENT}

\section{RÉSUMÉ NON TECHNIQUE}

Cet article propose une méthode pour mesurer les barrières à l'entrée dans les activités de services à partir de l'information qualitative disponible sur ces barrières. Elle est appliquée ici à trois secteurs (télécommunications fixes et mobiles, distribution) et à onze pays.

Les réponses au questionnaire de la Queen Mary University nous fournissent les informations qualitatives initiales quant aux restrictions appliquées par chaque pays dans chaque secteur. Notre travail consiste d'abord à coder ces réponses et à leur attribuer un score selon leur caractère plus ou moins restrictif. Ces scores sont rassemblés en un indicateur synthétique de restriction des échanges (STRI) par une analyse en composante principale, laquelle évite une pondération subjective.

L'étape suivante consiste à calculer un équivalent tarifaire correspondant à ce STRI. En considérant que les mesures réglementaires créent un écart entre le coût et le prix, nous considérons le STRI comme variable explicative de la marge de profit dans un secteur, à côté d'autres variables de contrôle. L'estimation économétrique est réalisée à partir des données de firmes des trois secteurs sur un échantillon plus large de pays (données fournies par Dihel et Sheperd, 2007). On en déduit l'effet moyen du STRI sur la marge (coefficient de la variable STRI).

En appliquant cet effet moyen aux STRI calculés pour chacun des onze pays, nous pouvons alors déduire un équivalent tarifaire des barrières dans chacun des trois secteurs. On observe alors que plus de la moitié des équivalents tarifaires sont supérieurs à $50 \%$, un sur six est supérieur à $100 \%$.

Outre ces résultats, ce travail a un double apport méthodologique : il propose un codage utile pour de futures études qualitatives ; il présente des améliorations techniques pour l'estimation des indices de restriction aux échanges et de leur impact sur les marges des entreprises. 


\section{RÉSUMÉ COURT}

Nous calculons des équivalents ad valorem (EAV) de la réglementation appliquée par un groupe de pays émergents dans trois secteurs de services: télécommunications fixes et mobiles et distribution. Tout d'abord, partant d'une information qualitative sur les restrictions imposées par chaque pays dans chacun des secteurs, nous la traduisons en scores chiffrés auxquels nous appliquons une approche statistique multivariée pour obtenir un indicateur synthétique de restriction des échanges (STRI). Dans une deuxième étape, nous estimons l'impact du STRI sur les marges des entreprises, à partir d'une méthode évitant l'approche habituelle en deux temps. Enfin, cet impact est utilisé pour calculer les équivalents tarifaires des STRI. Nous observons que plus de la moitié des équivalents tarifaires sont supérieurs à $50 \%$, un sur six est supérieur à $100 \%$.

Classification JEL : F13

Mots-clefs : $\quad$ Services; équivalents ad valorem 


\title{
ASSESSING BARRIERS TO TRADE IN THE DISTRIBUTION AND TELECOM SECTORS IN EMERGING COUNTRIES
}

\author{
Lionel Fontagné $^{*}$ Cristina Mitaritonna ${ }^{* *}$
}

\section{INTRODUCTION ${ }^{1}$}

Much of the studies addressing trade barriers in services have been relying on trade equation residuals to estimate tariff equivalents. The objective of this study is on the contrary to rely on the observed sector-specific regulatory variables. The advantages of such an approach are obvious. Gravity equation residuals may be affected by potential specifications errors such as omitted variables and poor quality of the underlying data. Also such approaches do not address local presence, which is the principal mode of service provision abroad. We will illustrate this method for three sectors of services - distribution, fixed telecom, mobile telecom - and a sample of 11 emerging countries. ${ }^{2}$

The survey methodology applied here has the advantage to rely on direct evidence from applied regulations, however it comes at a cost. This technique indeed is highly resource consuming, and this is why this method is unlikely to be applied across a wide range of sectors and countries. First qualitative information on barriers to services trade need to be collected. It is important that all the relevant restrictions are considered. As this asks for an advanced knowledge of the sector, this first stage is normally conducted through a survey obtained from several acknowledged experts.

In our study we managed to treat information on services regulations existing in the mid2000s on three services sectors (Distribution, Fixed Telecom and Mobile telecom) in Argentina, Brazil, China, Egypt, India, Indonesia, Malaysia, Morocco, Singapore, Thailand, Philippines and Tunisia, as provided by the Queen Mary University (See Queen Mary University, 2009).

\footnotetext{
* Paris School of Economics, Université Paris 1 ** CEPII.

${ }^{1}$ This research has received financial support by the European Commission under contract $N^{\circ}$ SI2.489.629 implementing Framework Contract $N^{\circ}$ TRADE/07/A2. The views expressed in this paper do not engage the European Commission. We are indebted to Queen Mary University and Development Solutions and Nora Dihel for providing much of the data used in this research. All errors remain ours. We acknowledge support by the CIREM.

${ }^{2}$ One questionnaire could not be coded (distribution in Indonesia) hence we may consider 10 or 11 countries depending of the sectors.
} 
An important part of this work was coding all the responses collected by the Queen Mary University, on a number of assumptions. We ensured that the coding process of this qualitative information remained fully transparent. ${ }^{3}$ In the second step all the qualitative information (e.g. the modes of attribution of licenses is different for foreigners; price caps are often determined by authorities, etc...) need to be transformed into quantitative data by an accurate scoring of the actual restriction according to their restrictiveness. The more stringent the restriction, the higher the score. Finally all the scores are synthesized in a unique indicator, the so called "trade restrictiveness index" (STRI), ${ }^{4}$ weighting together all the restrictions. We used an appropriate statistical method, the Principal Component analysis (PCA), to avoid assigning subjective weights (Section 2.1).

The second step was to enter the synthetic STRI as an explanatory variable in an econometric model, where the dependent variable is the price-cost margins of firms operating in a given sector. The methodology applied here assumes that regulatory measures create a wedge between price and cost. Thus, the price-cost margin is indicative of the magnitude of the barriers, when determinants other than regulatory measures are properly controlled for (e.g. market concentration).

Finally both STRI and the average effect of the STRI on price cost margins were used to compute the corresponding tariff equivalents.

A significant limitation of the methodology is that the results from the empirical models do not differentiate the exact nature of the economic effects of the barriers (whether they are cost-increasing or rent-creating for incumbent firms). However, while information on firmlevel margins is relatively freely available, data on costs and prices separately is not. At the stage the available information allows only the net effect to be measured.

As compared to the existing literature, we made an improvement to the econometric estimation methods, where a parsimonious method (clustered errors) made it possible to provide an elegant simplification to the usual two-stage approach and to obtain more precise estimates. Our difficulty was in having a sample of countries large enough to secure variance in the data. We are indebted to Nora Dihel for access to her large dataset (Dihel, 2007), which we used for the regression in order to obtain the average impact of the STRI on price cost margins (i.e. the $\beta$ coefficient of STRI).

In relation to relevance for policy, we have introduced information on preferential trading arrangements as well as most favored nation (MFN) exemptions. This allowed us to compute preferential margins and rents.

\footnotetext{
${ }^{3}$ We provide in Appendix 1 the Coding schemes for the three sectors, while the file summarizing coding assumptions is available to the interest reader upon request.

${ }^{4}$ We will use the acronym STRI instead of TRI to avoid any confusion with the TRI approach used elsewhere in the literature on protection measurement.
} 
The remaining of this paper is organized as follows. Section 2 describes the methodology used to calculate the STRIs; Section 3 explains how ad valorem equivalents were computed; and Section 4 concludes.

\section{Methodology to Construct Syntethic Trade RESTRICTIVENESS INDEXES}

This section focuses on the computation of aggregate STRIs for fixed telecom, mobile telecom and distribution, for selected emerging economies (Argentina, Brazil, Egypt, India, Indonesia, Malaysia, Morocco, Singapore, Thailand, Philippines and Tunisia). The calculation of STRIs is based in information gathered from the responses to detailed questionnaires provided by the Queen Mary University. Although the data we received was extremely detailed, it does not contain information on separate restrictions related to the four modes of services provisions. Accordingly our restrictiveness indexes, as well as the tariff equivalents, are global indexes instead of modal ones. We applied a multivariate statistical approach, known as PCA, in order to construct STRIs starting from the information contained in the questionnaires.

\subsection{Construction of the STRI}

A series of steps is involved in the calculation of STRI. Some important improvements are proposed in this paper, whose explanation requires detailed description of the methodology used.

First, the collection of qualitative information on different regulations, ${ }^{5}$ and its coding on a zero to 1 scale to reflect increasing restrictiveness.

After collecting data on trade restrictions by sector equal weights were assigned to each barrier identified. We avoid attributing subjective weights to different restrictions; ${ }^{7}$ weights are derived directly from data derived using the PCA technique pioneered in the field of economic regulations by the OECD (Gonenc \& Nicoletti, 2000; Steiner, 2000) and used extensively thereafter (Copenhagen Economics, 2005; Dihel, 2007; Marouani, 2009).

Intuitively PCA is a variable reduction procedure. It is appropriate for measures for a number of observed variables in order to develop a smaller number of artificial variables (or principal components). In particular, as some variables are correlated, it is possible to reduce the number of observed variables into a smaller number of principal components that are able to account for most of the variance in the observed variables.

\footnotetext{
5 Our source of information on trade barriers is Queen Mary University and Development Solutions (2009).

${ }_{7}^{6}$ See Tables A-1 to A-3 in the Annex for coding problems in different sectors.

${ }^{7}$ In the original work on TRI by a team of researchers from the Australian Productivity Commission and the University of Adelaide (see e.g. Warren, 2001; Kalirajan, 2000), scores and weights are based on subjective assignments.
} 
More formally the STRI is considered to be an abstract conceptual variable that is assumed to be linearly dependent on a set of $\mathrm{n}$ observable components, which in this case are the various restrictions, plus an error term. The total variation in the STRI then is made up of two orthogonal parts: a) variation due to the original variables; b) variation due to the error.

Starting with the $\mathrm{n}$ collected variables on regulations, each is initially normalized by subtracting its mean value and dividing by its standard deviation. Then a correlation matrix $\mathrm{C}$ ( $\mathrm{n} \times \mathrm{n}$ matrix) is calculated based on the standardized variables, to solve the equation $|\mathrm{C}-\lambda \mathrm{I}|$ $=0$ for $\lambda$. This provides a $n^{\text {th }}$ degree polynomial equation in $\lambda$ and hence $\mathrm{k} \leq \mathrm{n}$ roots known as the eigenvalues of the correlation matrix $\mathrm{C}$. Next $\lambda$ is arranged in descending order of magnitude, as $\lambda 1>\lambda 2>\ldots \lambda \mathrm{n}$. Corresponding to each value of $\lambda$, the matrix equation (C$\lambda \mathrm{I}) \alpha=0$ is solved for the $n x$ leigenvectors $(\alpha 1, \alpha 2 \ldots \alpha \mathrm{n})$. We then multiply each of the sets of raw data from the initial matrix containing the normalized information on barriers, by each of the eigen vectors to obtain $\mathrm{n}$ principal components variables, which have special statistical properties in terms of variance. In fact PCA computes an orthogonal coordinate system such that the greatest variance in the orthogonal projection for the initial data lies in the first coordinate (first principal component), the second greatest variance lies in the second coordinate (second component), and so on. Finally, the STRI is calculated as the weighted average of the retained principal components, where weights are equal to the eigenvalues of the correlation matrix $\mathrm{C}$, which ultimately represents the proportion of variance of each principal component $($ e.g. . $\lambda 1=\operatorname{var}(\mathrm{PC} 1), \lambda 2=\operatorname{var}(\mathrm{PC} 2) \ldots \lambda \mathrm{n}=\operatorname{var}(\mathrm{PCn}))$.

How many components need to be retained is an empirical matter; most practitioners retain all components with an eigenvalue greater than 1 (considering the component to be as informative as the original data). ${ }^{8}$ We can use all the components, but previous studies calculating STRIs in services use only the first component (e.g. Dihel and Sheperd, 2007). This means that much information is excluded, since, despite its importance, the first component represents only a part of the original variance (e.g. in our data, in the distribution sectors the first component explains only $0.32 \%$ of the original variance).

In order to illustrate this difference, we calculate the STRI first using only the first component and then using all relevant components (e.g. those with an eigenvalue greater than 1). Based on the different variants, the STRI are scaled so as to assign the value zero to the most liberal country. The results of the aggregate indices are shown in Figure 1. The graphs compare the results for the aggregate STRI using only the first component and then all the components. The countries with the lowest STRI scores have the most liberal trade regimes.

We can see that considering just one component strongly affects the results not only in terms of size but more importantly in terms of policy. A country that seems to be very well protected when using just the first principal component may turn out to be much less so when

\footnotetext{
${ }^{8}$ The number of components retained varies from sector to sector; here we use 4 components for each of the mobile and fixed telecommunications, and 3 components for distribution.
} 
all the relevant information is used to construct the STRI (e.g. Brazil in fixed telecommunication).

\section{Figure 1: STRI with one component and weighted components}

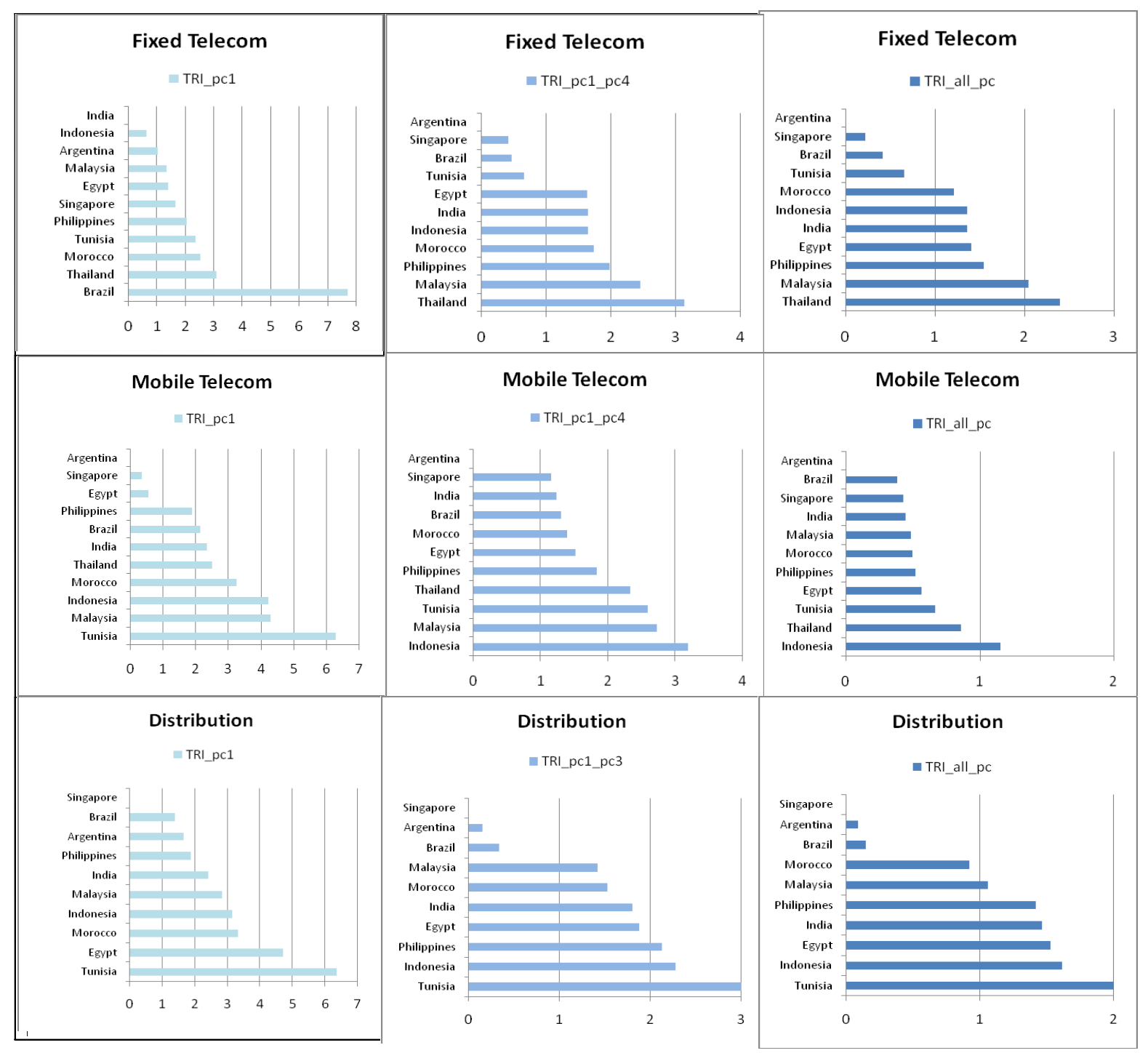

How we calculate the tariff equivalents by sector for the 11 emerging economies is described in Section 3, subsection 3.2. 


\section{COMPUTING AD VALOREM EQUIVALENTS}

The main objective of the study is to translate the restrictions in the services sectors, as measured by the STRIs index, into tariff equivalents, which can be thought of as hypothetical taxes, equivalent to the actual barriers.

In order to get tariff equivalents by sector for the emerging economies under analysis, two sets of information are required. First we need the value of the STRI, as calculated in Section 2.1. Second we need to measure how barriers (STRIs) affect the price-cost margin of service provisions. In this section we estimate the average impact of barriers to service provision on firm`s price -cost margins, for each of the three sectors considered.

For this second step we need a larger set of countries. Taking only the eleven emerging economies, we will have a very small number of observations, which will not allow us to perform the estimations needed. We are grateful to Nora Dihel for allowing access to her dataset which contains data for more than 90 firms for the two telecommunication sectors from 28 countries $^{9}$ and 380 firms for the distribution one from 33 countries, ${ }^{10}$ over the period 2002-2004. Moreover, the dataset includes qualitative information about restrictions to recalculate the STRIs for all the countries considered in this second stage.

It should be pointed out that even if we use the same dataset, as in Dihel and Sheperd, 2007, our work is novel in terms of both the calculation of the STRIs and the applied econometric specifications.

\subsection{Econometric specification}

The pattern of service provision generally requires local presence of the service provider. The exception is mode I trade in services, which represents a minor part of total trade in services within the GATS (General Agreement on Trade in Services) definition. Also, provision of services is generally regulated by a public authority. These regulations are enforced for a series of reasons ranging from the need to ensure that the provider is properly qualified (law, surgery, etc.) to the need to ensure that the service provider is not taking unwarranted risks (banking, finance). Accordingly, the enforcement of regulation depends on a mix of informational asymmetries and potential externalities.

Regulations have been applied at national level in an uncoordinated manner, which has resulted in differences across countries - a patter not specific to services. It requires firms to

\footnotetext{
${ }^{9}$ The countries included in the telecommunication sectors are the : a large number of European economies (Austria, Czech Republic, Denmark, Finland, France, Germany, Greece, Italy, Netherlands, Portugal, Spain, Switzerland, UK), selected countries in Asia (China, India, Japan, Korea, Malaysia, Thailand), Latin American (Argentina, Brazil, Chile, Peru), North America (Canada, USA and Mexico) and Australia and New Zealand.

${ }^{10}$ The economies considered in the distribution sector are the same as in the tecommunication sectors (see note 9) plus five more countries: Honk Kong, Indonesia, Singapore, Sweden and Turkey.
} 
bear specific fixed costs to adapt their supplies for different destination markets (Kox and Nordas, 2007).

In addition to this somewhat classical dimension to differences in domestic regulation, is the risk that in services, domestic and foreign providers may not receive similar treatment, depending on the GATS commitments in the different countries. Regulation generally increases the real resource costs of doing business (e.g. by requiring excessive paperwork) while at the same time limiting competition (creating pure rents for incumbent firms). The two effects impact on prices in the same direction: prices should rise. But discrimination against foreign providers should not increase their costs of producing, unless they produce abroad. Thus, ultimately what is affected by restrictions is the price cost margin in the domestic market of the country enforcing the regulations.

The question that is addressed in this section, therefore, is to what extent discriminatory regulations impact on the price-cost margins of firms (domestic or foreign) located in a given country, and in a given industry. The main difficulty lies in disentangling the specific effects of the regulation from the effects of other determinants. Each firm's profitability is affected by several factor specific to that firm (e.g. the market share of the considered firm, the firm size or the operational efficiency) along with other sectoral or economic-wide variables.

Industry characteristics, such as the capital intensity, may impact on all firms in the same way in a given country, but not necessarily in all countries. Also, the presence of at least one MFN exemption in the considered sector will impact on all local firms in the same way.

All in all, when econometrically estimating the relationship between mark ups and the barriers to services provisions, the first challenge is to control for the various determinants of the price cost margins while accounting for collinearity among the explanatory variables.

A second empirical challenge is to properly take account of the various dimensions of the data used: firm, sector and country level. In a given industry and a given country, all firms will be affected in the same way by certain sectoral characteristics. As a consequence, when individual price costs margins are regressed on their determinants, sectoral characteristics will be repeated as many times as there are firms in the particular industry in a given country.

A third empirical factor is that countries discriminate not only between domestic and foreign providers of services, but also among foreign providers as a result of their involvement on Regional Trade Agreements (RTAs).

In the following, we use a through econometric analysis to measure, for each industry separately, the direct impact of the restrictiveness of national regulations (STRIs) to service provisions, dealing with all the empirical questions mentioned above. The estimations of the average impact of the STRIs, for the fixed telecom, mobile telecom and distribution, will be used in subsection 3.2 to translate the synthetic STRIs computed in sub-section 2.1 into valorem equivalents. 


\section{Data and variables}

Our objective is to measure the average economic impact of the barriers applied to three services sectors: fixed telecom, mobile telecom and distribution.

For each service sector separately, we estimate the following econometric model:

$$
\mathrm{PCM}_{\mathrm{fic}}=\mathrm{c}+\alpha\left(\text { controls }_{\mathrm{fic}}\right)+\gamma\left(\text { controls }_{\mathrm{ic}}\right)+\beta \mathrm{STRI}_{\mathrm{ic}}+\varepsilon_{\mathrm{fic}}
$$

The price-cost margin for each firm (subscript $f$ ) in a given sector (subscript i) across countries (subscript c) is explained by a constant, a set of firm and country control variables, the aggregate STRIs representing the restrictiveness of the regulation applied by each country in that sector and a white error term.

Two decisions are central: the set of variables to be included as controls and the type of STRIs (those computed considering the first principal component only, the weighting average of the most relevant components or the weighting average of all the components).

The main interest would be in the magnitude of the coefficient $\beta$. However, its sign is also important. If $\beta$ is positive we will interpret the barriers as rent-creating. On the contrary if the sign is negative the barriers would be cost increasing. Obviously services restrictions might affect price and costs simultaneously, however to disentangle the two effects we would need data on prices and costs separately at the firm and sectoral level. Unfortunately such data is available for a very limited number of countries, so we have to rely on the information on firm level margins which is relatively easier to get.

All the data necessary to perform econometric estimations is the same as in Dhiel and Sheperd (2007). The number of observations, and the list of variables, varies from one sector to another. The dataset contains yearly data for more than 90 firms for the two telecommunication sectors from 28 countries and 380 firms for the distribution one from $33^{11}$ countries, over the period 2002-2004. Moreover the dataset includes variables at the sector and country level that might influence the firm's profitability, as well as qualitative information about restrictions necessary to recalculate the STRIs for all the countries considered in the regressions.

As already mentioned, even using the same data, our work differs from the study by Dihel and Sheperd in two ways. First the aggregate trade restrictiveness index is recomputed for each country and industry, relying on a different methodology that is consistent with the one applied in sub-section 2.1. Hence, we consider either the STRI computed via the first principal component or as the weighted average of the most relevant principal components. Second, we use an econometric specification that differs in terms of the variables considered and the econometric technique applied.

\footnotetext{
${ }^{11}$ For the complete list of countries included in the dataset see notes 9 and 10.
} 
For the three services sectors, the price-cost margin of each firm is defined as the sum of the earnings before interest and taxes (EBIT) and depreciation, divided by net sales.

Concerning the controls affecting the firm`s profitability, other than the STRIs, the list of available variables varies sector by sector. For all the three sectors the econometric models includes controls for:

- The productivity of the firm, defined as log of the ratio of net sales over number of employees;

- The firm market share defined as the log of ratio of net sales over total industry net sales;

- The annual $(\log )$ growth in the sales of the considered firm;

- The capital intensity of production defined as the log of ratio of total capital over net sales, measured at firm level;

- The STRIs for each country, alternatively computed considering the principal component only or as the weighted average of the main principal components. Obviously our preferred specification is that which includes the weighted STRI.

- Previous STRI interacted with a dummy variable equal to 1 if the country has signed at least one RTA covering the sector;

- Same STRI interacted with a dummy variable equal to 1 if a country has at least one MFN exemption for the sector;

The dataset includes also a large number of other variables, used in the econometric specifications by Dhiel and Sheperd (2007) (see Appendix 2). The list of the available variables raises the problems of potential collinearity between certain of them (e.g. net sales and efficiency of supply ${ }_{13}^{12}$ and the underlying economic rationale for introducing some of them (e.g. solvency ratio, ${ }^{13}$ available for the distribution sector). We avoided using as controls collinear variables, and we performed alternatively regressions with and without the solvency ratio (See Table 3).

Estimations including some other industry level variables, such as (log) growth in industry revenue, were performed but are not reported here given the limited gain from introducing them.

\footnotetext{
12 The efficiency of supply of the firm is defined as the ratio of global inventories over net sales.

${ }^{13}$ Solvency ratio is defined as the ratio of total debt over the sum of total capital and short term debt
} 
As correctly observed by Dihel and Sheperd (2007), the combined presence of firm and country level variables leads to incorrect statistical inference. However, the problem of serial correlation, originally pointed out by Moulton (1990), can be best handled by clustering the error terms at country level instead of performing two-stage estimations (Wooldrige, 2003).

Finally, there is the problem of incomplete data for the explanatory variables: depending on the assumptions made in "filling in the blanks" the number of observations and, thus, the estimated parameters differ. Accordingly, in the last series of estimations the blanks are not "filled in" with appropriate assumptions. These additional results are provided for information only in Appendix 3, and are less robust. For the ad valorem equivalents computed in subsection 3.2 we rely on the parameters presented in the main text.

\subsection{Results}

We start by replicating the approach in Dihel and Sheperd (2007) - namely by relying on the STRI calculated using only the first principal component (TRI_1), but proceed using a more parsimonious estimated equation (see above). The results are presented in columns (1) to (3) in Table 1, while columns (4) to (6) use the weighted average of the most relevant principal components (TRI_weighted).

The results are encouraging given the limited number of observations: most selected variables are significant, and roughly half of the variance in individual price cost margins is explained. The only variable that is not significant is firm productivity. Firm's market share shows an increased price cost margin, consistent with the usual imperfect competition framework. The last three columns in the table show that this impact is particularly significant, where the maximum amount of information is extracted from the individual components of the STRI. The growth of firm sales is also positively related to price cost margin, though with a wider margin of error. More capital intensive firms are also more profitable. We could argue that being more profitable allows higher investment. Accordingly reverse causality is not excluded.

We next turn to our variables of interest, related to service regulation restrictiveness. First, we can see that the STRI has no significant effect on the price-cost margins of the individual firms in columns (1) and (4), when it is introduced in the equation. This somewhat deceptive result is not altogether surprising however, since what is important is the discriminatory enforcement of these regulations across trading partners. When the terms are interacted between STRI and RTA or MFN are introduced, the STRI are shown to have a significant impact on price cost margins at the $1 \%$ confidence level. This impact is negative suggesting that the cost-enhancing effect of the regulations dominate the anti-competitive advantages to incumbent firms. There is no way of disentangling these impacts given our data. 
Table 1: Results of estimation for the fixed telecom sector

\begin{tabular}{|c|c|c|c|c|c|c|}
\hline $\begin{array}{l}\text { Dep var: log firm level } \\
\text { price-cost margins }\end{array}$ & (1) & (2) & (3) & (4) & (5) & (6) \\
\hline \multirow[t]{2}{*}{ Productivity } & 0.0312 & 0.0601 & 0.0714 & 0.0330 & 0.0610 & 0.0904 \\
\hline & $(0.106)$ & $(0.112)$ & $(0.113)$ & $(0.104)$ & $(0.106)$ & $(0.112)$ \\
\hline \multirow[t]{2}{*}{ Market share } & $0.0753 * *$ & $0.0712 *$ & $0.0645^{*}$ & $0.0740^{* *}$ & $0.0712 * *$ & $0.0710^{* *}$ \\
\hline & $(0.0313)$ & $(0.0345)$ & $(0.0325)$ & $(0.0303)$ & $(0.0328)$ & $(0.0306)$ \\
\hline \multirow[t]{2}{*}{ Sales growth } & $0.395^{*}$ & $0.353^{*}$ & 0.300 & $0.394 *$ & $0.357^{*}$ & $0.311^{*}$ \\
\hline & $(0.222)$ & $(0.196)$ & $(0.178)$ & $(0.218)$ & $(0.195)$ & $(0.176)$ \\
\hline \multirow[t]{2}{*}{ Capital intensity } & $0.658 * * *$ & $0.643 * * *$ & $0.635^{* * *}$ & $0.660 * * *$ & $0.641 * * *$ & $0.618^{* * *}$ \\
\hline & $(0.0952)$ & $(0.0886)$ & $(0.0842)$ & $(0.0960)$ & $(0.0893)$ & $(0.0775)$ \\
\hline \multirow[t]{2}{*}{ TRI_1 } & -0.0435 & $-0.201 * * *$ & $-0.194 * * *$ & & & \\
\hline & $(0.0721)$ & $(0.0281)$ & $(0.0283)$ & & & \\
\hline \multirow[t]{2}{*}{ TRI_1*RTA } & & $0.226 * * *$ & $0.203 * * *$ & & & \\
\hline & & $(0.0657)$ & $(0.0702)$ & & & \\
\hline \multirow[t]{2}{*}{ TRI_1*MFN } & & & $0.182 *$ & & & \\
\hline & & & $(0.0885)$ & & & \\
\hline \multirow[t]{2}{*}{ TRI_weighted } & & & & -0.0753 & $-0.322 * * *$ & $-0.280 * * *$ \\
\hline & & & & $(0.125)$ & $(0.0500)$ & $(0.0433)$ \\
\hline \multirow[t]{2}{*}{ TRI_weighted*RTA } & & & & & $0.374 * * *$ & $0.343^{* * *}$ \\
\hline & & & & & $(0.0923)$ & $(0.0914)$ \\
\hline \multirow[t]{2}{*}{ TRI_weighted*MFN } & & & & & & $0.324^{*}$ \\
\hline & & & & & & $(0.167)$ \\
\hline \multirow[t]{2}{*}{ Constant } & $-1.489 * *$ & $-1.707 * *$ & $-1.844 * *$ & $-1.471^{* *}$ & $-1.739 * *$ & $-2.080 * * *$ \\
\hline & $(0.621)$ & $(0.679)$ & $(0.678)$ & $(0.621)$ & $(0.646)$ & $(0.625)$ \\
\hline Observations & 99 & 99 & 99 & 99 & 99 & 99 \\
\hline R-squared & 0.436 & 0.454 & 0.462 & 0.436 & 0.454 & 0.473 \\
\hline \multicolumn{7}{|c|}{ Robust standard errors in parentheses } \\
\hline \multicolumn{2}{|c|}{$* * * p<0.01, * * p<0.05, * p<0.1$} & & & & & \\
\hline
\end{tabular}


We can see that preferential arrangements in the service sector have the opposite effect as shown by the parameter estimate for the variable for RTA. They provide firms located in the partner countries that have signed these agreements, differential advantage over firms located in a third country. This 'margin of preference' is exploited in subsection 3.2 to compute associated rents.

Lastly, it is important to note that the presence of an exception to the MFN clause in the sector enhances the price cost margin and thus has a clear anti-competitive effect, and possibly at no cost. This information is also used in subsection 3.2 to calculate the equivalent subsidy provided to domestic firms.

Next, we turn to the mobile telecom sector and proceed as before. The results are reported in Table 2. Compared to the fixed telecom sector, sales growth does not have a significant impact on price cost margin. The reasons for this are associated with the pricing strategies of firms. Sales growth is only achieved at very high cost in this industry, where 'capturing' a new client is costly (e.g. in terms of the mobile set provided free to new subscribers). Market share, on the other hand, has a very significant and positive effect on price-cost margin. In addition, MFN exemptions do not have an effect on price cost margins. A tentative explanation for this is that the core issue, of new licences, is not controlled for here.

The last sector is distribution - results presented in Table 3. We observe a positive impact of sales growth, while market share is weakly significant. Here, again, capital intensity positively affects price cost margin. Productivity has a negative impact - pointing to the transfer of productivity gains to the consumer in a rather competitive sector - while solvency, as expected, is not significant. We obtain similar results for the other sectors considered in terms of the impact of the regulation, the exception being MFN, which is no longer significant, due to the already high competitive nature of the sector. 
Table 2: Results of estimation for the mobile telecom sector

\begin{tabular}{|c|c|c|c|c|c|c|}
\hline $\begin{array}{l}\text { Dep var: log firm level } \\
\text { price-cost margins }\end{array}$ & (1) & (2) & (3) & (4) & (5) & (6) \\
\hline \multirow[t]{2}{*}{ Productivity } & 0.158 & 0.135 & 0.135 & 0.158 & 0.126 & 0.143 \\
\hline & $(0.123)$ & $(0.125)$ & $(0.127)$ & $(0.117)$ & $(0.117)$ & $(0.130)$ \\
\hline \multirow[t]{2}{*}{ Market share } & $0.0776^{* * *}$ & $0.0761 * * *$ & $0.0777 * * *$ & $0.0767 * * *$ & $0.0758 * * *$ & $0.0836^{* * *}$ \\
\hline & $(0.0222)$ & $(0.0211)$ & $(0.0222)$ & $(0.0223)$ & $(0.0214)$ & $(0.0252)$ \\
\hline \multirow[t]{2}{*}{ Sales growth } & 0.351 & 0.211 & 0.194 & 0.362 & 0.243 & 0.226 \\
\hline & $(0.237)$ & $(0.176)$ & $(0.180)$ & $(0.236)$ & $(0.189)$ & $(0.182)$ \\
\hline \multirow[t]{2}{*}{ Capital intensity } & $0.613 * * *$ & $0.615 * * *$ & $0.607 * * *$ & $0.613 * * *$ & $0.611 * * *$ & $0.579 * * *$ \\
\hline & $(0.115)$ & $(0.116)$ & $(0.115)$ & $(0.114)$ & $(0.117)$ & (0.109) \\
\hline \multirow[t]{2}{*}{ TRI_1 } & 0.0143 & $-0.181 * * *$ & $-0.180 * * *$ & & & \\
\hline & $(0.0553)$ & $(0.0490)$ & $(0.0484)$ & & & \\
\hline \multirow[t]{2}{*}{ TRI_1*RTA } & & $0.250 * * *$ & $0.240 * * *$ & & & \\
\hline & & $(0.0387)$ & $(0.0407)$ & & & \\
\hline \multirow[t]{2}{*}{ TRI_1*MFN } & & & 0.0624 & & & \\
\hline & & & $(0.0912)$ & & & \\
\hline \multirow[t]{2}{*}{ TRI_weighted } & & & & 0.0501 & $-0.326 * * *$ & $-0.292 * * *$ \\
\hline & & & & $(0.128)$ & $(0.102)$ & $(0.0973)$ \\
\hline \multirow[t]{2}{*}{ TRI_weighted*RTA } & & & & & $0.507 * * *$ & $0.450^{* * *}$ \\
\hline & & & & & $(0.0971)$ & $(0.123)$ \\
\hline \multirow[t]{2}{*}{ TRI_weighted*MFN } & & & & & & 0.224 \\
\hline & & & & & & $(0.167)$ \\
\hline \multirow[t]{2}{*}{ Constant } & $-2.309 * * *$ & $-2.204 * * *$ & $-2.218 * *$ & $-2.348 * * *$ & $-2.260 * * *$ & $-2.421 * * *$ \\
\hline & $(0.768)$ & $(0.775)$ & $(0.789)$ & $(0.729)$ & $(0.725)$ & $(0.797)$ \\
\hline Observations & 91 & 91 & 91 & 91 & 91 & 91 \\
\hline R-squared & 0.412 & 0.439 & 0.440 & 0.412 & 0.439 & 0.449 \\
\hline \multicolumn{7}{|c|}{ Robust standard errors in parentheses } \\
\hline \multicolumn{2}{|c|}{$* * * p<0.01, * * p<0.05, * p<0.1$} & & & & & \\
\hline
\end{tabular}


Table 3: Results of estimation for the distribution sector

\begin{tabular}{|c|c|c|c|c|c|c|}
\hline $\begin{array}{l}\text { Dep var: log } \\
\text { firm level } \\
\text { price-cost } \\
\text { margins }\end{array}$ & (1) & (2) & (3) & (4) & (5) & (6) \\
\hline Sales growth & $\begin{array}{r}0.184 * * * \\
(0.0423)\end{array}$ & $\begin{array}{r}0.205 * * * \\
(0.0432)\end{array}$ & $\begin{array}{r}0.194 * * * \\
(0.0461)\end{array}$ & $\begin{array}{r}0.186 * * * \\
(0.0388)\end{array}$ & $\begin{array}{r}0.194 * * * \\
(0.0462)\end{array}$ & $\begin{array}{r}0.176^{* * *} \\
(0.0520)\end{array}$ \\
\hline Market share & $\begin{array}{r}0.000873 \\
(0.0107)\end{array}$ & $\begin{array}{c}0.0161 * \\
(0.00837)\end{array}$ & $\begin{array}{r}0.0175 \\
(0.0124)\end{array}$ & $\begin{array}{l}0.00359 \\
(0.0119)\end{array}$ & $\begin{array}{r}0.0176 \\
(0.0112)\end{array}$ & $\begin{array}{r}0.0172 * \\
(0.00886)\end{array}$ \\
\hline $\begin{array}{l}\text { Capital } \\
\text { intensity }\end{array}$ & $\begin{array}{l}0.609 * * * \\
(0.0342)\end{array}$ & $\begin{array}{l}0.617^{* * *} \\
(0.0264)\end{array}$ & $\begin{array}{r}0.639 * * * \\
(0.0319)\end{array}$ & $\begin{array}{r}0.636 * * * \\
(0.0428)\end{array}$ & $\begin{array}{r}0.646 * * * \\
(0.0317)\end{array}$ & $\begin{array}{r}0.647 * * * \\
(0.0246)\end{array}$ \\
\hline Productivity & $\begin{array}{l}-0.144 * * \\
(0.0529)\end{array}$ & $\begin{array}{r}-0.192 * * * \\
(0.0485)\end{array}$ & $\begin{array}{r}-0.154 * * * \\
(0.0417)\end{array}$ & $\begin{array}{l}-0.118 * * \\
(0.0460)\end{array}$ & $\begin{array}{r}-0.157 * * * \\
(0.0416)\end{array}$ & $\begin{array}{r}-0.144 * * * \\
(0.0485)\end{array}$ \\
\hline Efficiency & $\begin{array}{l}-0.0112 \\
(0.0336)\end{array}$ & $\begin{array}{l}-0.0128 \\
(0.0319)\end{array}$ & $\begin{array}{r}-0.0223 \\
(0.0313)\end{array}$ & $\begin{array}{l}-0.0206 \\
(0.0279)\end{array}$ & $\begin{array}{c}-0.0198 \\
(0.0295)\end{array}$ & $\begin{array}{r}-5.66 \mathrm{e}-05 \\
(0.0297)\end{array}$ \\
\hline Solvency & $\begin{array}{r}-0.0360 \\
(0.0269)\end{array}$ & $\begin{array}{r}-0.0386 \\
(0.0233)\end{array}$ & $\begin{array}{r}-0.0327 \\
(0.0229)\end{array}$ & $\begin{array}{l}-0.0240 \\
(0.0274)\end{array}$ & $\begin{array}{l}-0.0338 \\
(0.0220)\end{array}$ & \\
\hline TRI_1 & $\begin{array}{l}-0.0710^{*} \\
(0.0413)\end{array}$ & $\begin{array}{r}-0.141 * * * \\
(0.0322)\end{array}$ & $\begin{array}{r}-0.139 * * * \\
(0.0321)\end{array}$ & & & \\
\hline TRI_1*RTA & & $\begin{array}{r}0.131 * * * \\
(0.0267)\end{array}$ & $\begin{array}{r}0.0919 * * * \\
(0.0232)\end{array}$ & & & \\
\hline TRI_1*MFN & & & $\begin{array}{c}0.0661 * \\
(0.0337)\end{array}$ & & & \\
\hline TRI_weighted & & & & $\begin{array}{l}-0.154 * * \\
(0.0719)\end{array}$ & $\begin{array}{r}-0.248 * * * \\
(0.0500)\end{array}$ & $\begin{array}{r}-0.247 * * * \\
(0.0470)\end{array}$ \\
\hline $\begin{array}{l}\text { TRI_weighted* } \\
\text { RTA }\end{array}$ & & & & & $\begin{array}{l}0.129 * * * \\
(0.0311)\end{array}$ & $\begin{array}{r}0.116^{* * *} \\
(0.0365)\end{array}$ \\
\hline $\begin{array}{l}\text { TRI_weighted* } \\
\text { MFE }\end{array}$ & & & & & & $\begin{array}{r}0.0665 \\
(0.0422)\end{array}$ \\
\hline Constant & $\begin{array}{r}-0.840 * * \\
(0.312)\end{array}$ & $\begin{array}{r}-0.519 \\
(0.304)\end{array}$ & $\begin{array}{r}-0.735 * * * \\
(0.247)\end{array}$ & $\begin{array}{r}-0.969 * * * \\
(0.283)\end{array}$ & $\begin{array}{r}-0.606^{* *} \\
(0.260)\end{array}$ & $\begin{array}{r}-0.763 * * \\
(0.293)\end{array}$ \\
\hline Observations & 388 & 360 & 360 & 388 & 360 & 390 \\
\hline $\begin{array}{l}\text { R-squared } \\
\text { Robust standard } \\
* * * \mathrm{p}<0.01, * *\end{array}$ & $\begin{array}{r}0.499 \\
\text { ors in paren } \\
05, * \mathrm{p}<0.1\end{array}$ & 0.583 & 0.588 & 0.506 & 0.588 & 0.567 \\
\hline
\end{tabular}




\subsection{Calculating Tariff Equivalents}

In this section we use both the value of the STRI for our selected emerging economies, for each of the three service sectors (see Section 2.1) and the average impact of the STRI on the price cost margin (the $\beta$ coefficient for the TRI estimated in section 3.2) to compute the ad valorem equivalents. The tariff equivalent applied by a given country $c$ in a particular sector $i$ is simply:

$$
t_{i c} \equiv 100\left(\frac{P C M_{i c}-P C M_{0 c}}{P C M_{0 c}}\right)=100\left(e^{\beta^{*} T R I_{c-1}}\right)
$$

where $P C M_{0 c}$ refers to the price cost margin related to country $c$ were it to have a TRI of zero, and all other factors were unchanged. More particularly, we rely on the coefficient estimated on the STRI when interaction with RTA and MFN are introduced and when more than one component is included in the construction of the STRI. In general, we use the coefficient in column (6) of the tables in subsection 3.2. In terms of the value of STRI calculated in section 2.1 , in order to maintain compatibility with the regression results, we use the index calculated using the relevant principal components (results presented in the main text of this section). However, for completeness, in Appendix 4 we include the results for the tariff equivalents using the STRI constructed with all principal components. Obviously, in this latter case, the smaller sizes of the STRI translate into smaller tariff equivalents. Also, the estimated coefficient is associated with a standard error. In order to take this into account, we recalculated the tariff adding and subtracting to $\beta$ the value of $\sigma$, which gives us lower and upper values respectively for the protection. We can see from Tables 4 to 6 how a small variation in $\beta$ impacts strongly on the value of the tariff equivalent obtained.

Another novelty of our approach is that we consider the effects of RTAs and, in the case of fixed telecom, the effects of MFN exemptions. We noted in the previous section that trade barriers combined with RTA, tend to have rent-creating effects. Based on this information we calculated what we refer to in Tables 4 to 6 as the "Preferential margin", that is, the preference granted by the importing country to the countries with which it signed an RTA. TIn the case of the fixed telecom sector, we can also compute the ad valorem rent provided to local producers through the MFN exemption.

According to our calculations, Argentina, Singapore and Brazil seem to be the least protected economies in all three sectors studied.

The outcome for fixed telecom for Argentina, although in line with previous studies (Dihel and and Sheperd, 2007), is rather surprising bearing in mind the dominant position of 
historical providers in the sector. ${ }^{14}$ However, the result can be explained by the lack of information on restrictive regulation enforced by this Latin American country, or by the way that the qualitative information is coded. Finally, the calculation of STRI index is also affected by the way the PCA weights the various responses.

Columns (2) and (3) in Table 4, provide two complementary pieces of information. Column (2) presents the percentage equivalent of the regulatory preferential margin associated to the presence of an RTA. For the partner countries having signed an RTA comprising clauses concerning the sector, the impact on firms providing services in the considered country is positive. Note that this impact is never large enough to overcome the negative impact of the regulation. But the interesting outcome is that providers of services originating from third countries are excluded from this preferential treatment. In addition, column (3) presents the percentage equivalent of the sum of the regulatory preferential margin and the rent conceded to domestic producers as a result of MFN exemption. Hence, the difference between columns (3) and (2) represents the rent accruing to domestic provider of services in the considered country. This rent is quite large for India, Indonesia, Morocco and Philippines.

Table 4: Tariff equivalents of regulations in the fixed telecom sector

\begin{tabular}{lccccc}
\hline & $(1)$ & + sigma $^{* *}$ & - sigma** & $(2)$ & $(3)$ \\
\hline Argentina & 0.0 & 0.0 & 0.0 & 0.0 & 0.0 \\
Singapore & 12.5 & 10.4 & 14.5 & -2.6 & -15.0 \\
Brazil & 14.3 & 11.9 & 16.7 & -3.0 & -16.8 \\
Tunisia & 20.7 & 17.2 & 24.2 & -4.1 & -22.9 \\
Egypt & 58.2 & 47.3 & 69.8 & -9.8 & -46.9 \\
India & 58.9 & 47.9 & 70.6 & -9.9 & -47.3 \\
Indonesia & 58.9 & 47.9 & 70.7 & -9.9 & -47.3 \\
Morocco & 62.7 & 50.9 & 75.5 & -10.4 & -49.0 \\
Philippines & 74.2 & 59.9 & 89.8 & -11.7 & -53.6 \\
Malaysia & 99.4 & 79.2 & 121.9 & -14.4 & -61.5 \\
Thailand & 141.3 & 110.5 & 176.5 & -18.0 & -70.4 \\
\hline
\end{tabular}

Note:

(1): Average impact of regulations applied to countries where there is no RTA

(2): Regulatory preferential margin in presence of RTA

(3): Sum of regulatory preferential margin and rent from MFN exemption

**: the tariff equivalent is calculated adding and subtracting to $\beta$ the value of $\sigma$

The rent-creating effect of MFN exemptions is not significant in the regressions for the mobile telecom and distribution sectors, which makes it impossible to compute the rent creating effect of this distortion (Tables 5-6).

\footnotetext{
${ }^{14}$ Information on the market share of the three historical providers ( $90 \%$ in the mid-2000s) in telecommunication is provided in the questionnaires.
} 
Table 5: Tariff equivalents of regulations in the mobile telecom sector

\begin{tabular}{lccccc}
\hline & $(1)$ & sigma** $^{*}$ & -sigma** $^{* *}$ & $(2)$ & $(3)$ \\
\hline Argentina & 0.0 & 0.0 & 0.0 & 0.0 & $\mathrm{~ns}$ \\
Singapore & 40.2 & 25.3 & 57.0 & -16.7 & $\mathrm{~ns}$ \\
India & 43.6 & 27.3 & 61.9 & -17.8 & $\mathrm{~ns}$ \\
Brazil & 46.2 & 28.8 & 66.0 & -18.6 & $\mathrm{~ns}$ \\
Morocco & 50.4 & 31.3 & 72.4 & -19.8 & $\mathrm{~ns}$ \\
Egypt & 55.8 & 34.4 & 80.5 & -21.3 & $\mathrm{~ns}$ \\
Philippines & 70.8 & 42.9 & 104.1 & -25.1 & $\mathrm{~ns}$ \\
Thailand & 97.4 & 57.4 & 147.5 & -30.8 & $\mathrm{~ns}$ \\
Tunisia & 112.9 & 65.5 & 173.9 & -33.6 & $\mathrm{~ns}$ \\
Malaysia & 121.9 & 70.1 & 189.3 & -35.0 & $\mathrm{~ns}$ \\
Indonesia & 153.6 & 86.0 & 245.8 & -39.6 & $\mathrm{~ns}$ \\
\hline
\end{tabular}

Note:

(1): Average impact of regulations applied to countries where there is no RTA

(2): Regulatory preferential margin in presence of RTA

(3): Sum of regulatory preferential margin and rent from MFN exemption

**: the tariff equivalent is calculated adding and subtracting to $\beta$ the value of $\sigma$

Table 6: Tariff equivalents of regulations in the distribution sector

\begin{tabular}{lccccc}
\hline & $(1)$ & + sigma $^{* *}$ & - sigma** $^{* *}$ & $(2)$ & $(3)$ \\
\hline Singapore & 0 & 0 & 0 & 0 & n.s. \\
Argentina & 3.9 & 3.1 & 4.7 & -1.8 & n.s. \\
Brazil & 8.8 & 7.0 & 10.7 & -4.0 & n.s. \\
Malaysia & 42.2 & 32.5 & 52.6 & -15.5 & n.s. \\
Morocco & 46.1 & 35.4 & 57.6 & -16.6 & n.s. \\
India & 56.3 & 42.9 & 71.0 & -19.3 & n.s. \\
Egypt & 59.1 & 44.9 & 74.7 & -20.0 & n.s. \\
Philippines & 69.5 & 52.4 & 88.5 & -22.4 & n.s. \\
Indonesia & 75.9 & 57.0 & 97.0 & -23.7 & n.s. \\
Tunisia & 110.9 & 81.5 & 145.0 & -30.1 & n.s. \\
Thailand & - & - & - & - & - \\
\hline
\end{tabular}

Note:

(1): Average impact of regulations applied to countries where there is no RTA

(2): Regulatory preferential margin in presence of RTA

(3): Sum of regulatory preferential margin and rent from MFN exemption

**: the tariff equivalent is calculated adding and subtracting to $\beta$ the value of $\sigma$ 
We observe that the level of revealed protection is highly sector specific. For instance, India is quite liberal in the mobile sector, but much stricter in the distribution sector. Tunisia has stricter regulation in distribution than for the fixed telecom sector. These differences are even more evident if we look at the results for tariff equivalents shown in Appendix 4.

Note that there is no ad valorem equivalent computed for Thailand in the distribution sector, since we could not use the questionnaire responses in this case.

\section{CONCLUSION}

The objective of this paper was to compute ad valorem equivalents for the regulation in three service sectors (i.e. fixed telecom, mobile telecom, distribution) applied by a group of emerging countries. We start with qualitative information on the restrictions applied by each country in each sector on the basis of which we applied a multivariate statistical approach, PCA, to transform this qualitative data into a synthetic index (STRI).

We extracted as much information as possible from the original data, based on a statistical criterion, weighting the different components based on their contribution to the whole variance. For this first stage we used detailed questionnaire responses provided by the Queen Mary University.

For the second stage, we used a large dataset provided by Dihel and Sheperd (2007) but a new econometric method, to estimate the average impact of STRI on firms ' price-cost margins. We proposed a parsimonious method, avoiding two-stage estimations, which provided consistent and significant parameters.

The estimated parameters were used to compute ad valorem equivalents, by applying them to the STRIs previously calculated. In addition to ad valorem equivalents of the regulation, our method provides ad valorem equivalents of the preferential margins and rents created by MFN exemptions clause.

The value added of our work is accordingly threefold. We provide a series of new tariff equivalents, based on precise estimates; a coding structure to guide future qualitative studies; and propose technical improvements to the estimation of restrictiveness indices and their impact on price cost margins. 


\section{REFERENCES}

Copenhagen Economics (2005), Economic Assessment of the Barriers of the Internal Market for Services. Final Report, Copenhagen, January.

Dihel N., Sheperd B. (2007), Modal estimates of services barriers. OECD, Trade Policy Working Paper, 51.

Gonenc R. and Nicoletti G. (2000), Regulation Market Structure and Performance in Air Passenger Transport, Working Paper 254, ECO/WKP(2000)27, Economics Department, OECD.

Kalirajan K (2000), Restriction on Trade in Distribution Services, Productivity Commisison Staff Research Paper, AusInfo, Camberra, August..

Kox H.L.M., Nordas H.K. (2007), Services trade and domestic regulation, Munich Personal RePEc Archive, http://mpra.ub.uni-muenchen.de/2116/

Marouani, M. and Munro L. (2009), Assessing barriers to trade in Services in the Mena Region, OECD Trade Policy Working Paper, 87.

Moulton B. (1990) An illustration of a Pitfall in Estimating the effects of aggregate Variables on Micro Units , Review of Economics and Statistics, 72(2): 334-338.

Queen Mary University of London and Development Solutions (2009), Study of the existing Level of Liberalisation in Selected Services Sectors, Final Report for the DG Trade.

Steiner F. (2000), Regulation Industry structure and performance in the Electricity Supply Industry, Working Paper 238, ECO/WKP(2000)11, OECD, Paris.

Warren T. (2000) The impact on Output of impediments of Trade in Telecommunications Services, in Findlay, C. and Warren T. (eds.) (2000), Impediments in Trade in Services: Measurement and Policy Implications, Routledge, London.

Wooldrige J. (2003), Cluster Sample Methods in Applied Econometrics, American Economic Review, 93(2): 133-138. 


\section{APPENDiX A: COMPONENTS OF THE RESTRICTIVENESS INDICES}

\section{Table A-1: Coding scheme for fixed telecom}

\begin{tabular}{lll}
\hline Variable Name & $\begin{array}{l}\text { Corresponding item(s) in the questionnaire is Criteria for assigning value } \\
\text { precise questions }\end{array}$ \\
\hline PolicyRestriction & A 1) Are there policy, legal or regulatory 1.00 : If restrictions exist for all segments, both \\
& $\begin{array}{l}\text { restrictions on the provision of fixed line for foreign and local firms } \\
\text { services? By any firm? }\end{array}$ & $0:$ If no restriction exists \\
& Intermediate values depending on actual \\
& restrictions & NB: If the restriction is only about licensing, it is \\
& not considered as a restriction, since such \\
& restriction actually applies in all countries.
\end{tabular}

PolicyRestriction A 1) Are there policy, legal or regulatory $1.00:$ If restrictions exist for all segments, both Foreign restrictions on the provision of fixed line for foreign and local firms services? By foreign firms? $\quad 0$ : If no restriction exists Intermediate values: the complement of the maximum foreign equity share allowed NB: If the restriction is only about licensing, it is not considered as a restriction, since such restriction actually applies in all countries.

\begin{tabular}{lll}
\hline Allowed Interconn & A 2) Is interconnection to the public switched 1.0: No \\
& network allowed legally? & $0.0:$ Yes \\
\hline MktEntryRestr & A 3) Are there market entry restrictions specific $1.0:$ If there are restrictions in all 3 sectors \\
& to the below market segments ? (Cable $0.67:$ for restrictions in 2 sectors \\
& television, fixed line internet, other) & 0.33 for restrictions in 1 sector \\
& & $0.0:$ No restrictions \\
\hline IncumbentSwitch & A 4) Are new market entrants required to use 1.0: Yes \\
Required & the incumbent's international gateway switch? $0.0:$ No \\
\hline ResalePermitted & A 5) Is 3rd party simple resale of lease line $1.0:$ If not permitted neither domestic nor \\
& capacity permitted? & international \\
& & $0.5:$ If permitted only in domestic sector \\
& & $0.0:$ if permitted
\end{tabular}

PrivateOwn

B 1) is private ownership in the provision of (1 - average maximum allowed share of private services permitted legally ? For existing owner) operators? for new entrants?

ForeignOwn $\quad$ B 2) is foreign ownership in the provision of (1- average maximum allowed share of foreign services permitted legally ? For existing owner) operators? For new entrants? 


\begin{tabular}{|c|c|}
\hline Variable Name & $\begin{array}{l}\text { Corresponding item(s) in the questionnaire is Criteria for assigning value } \\
\text { precise questions }\end{array}$ \\
\hline ForeignEqRestr & $\begin{array}{l}\text { B 3) Are there foreign equity restrictions on } 1.0 \text { : Yes } \\
\text { companies offering services in multiple market } 0.0 \text { : No } \\
\text { segments (local, long distance, international, } \\
\text { leased line, internet services)? }\end{array}$ \\
\hline WTORefPaper & $\begin{array}{l}1.0: \text { No } \\
\text { decrease by } 0.1 \text { for each checked item in the list } \\
0.0: \text { Yes }\end{array}$ \\
\hline LicensingProcedur & $\begin{array}{l}\text { C) 4) a)What are the main criteria/procedures } 0.1 \text { : license fee } \\
\text { new entrants must satisfy to be granted a }+0.1 \text { : competitive tender } \\
\text { service license? } \\
+0.2 \text { : economic needs test } \\
+0.1 \text { : submission of information } \\
+0.5 \text { discretionary decision by authority }\end{array}$ \\
\hline Internet License & $\begin{array}{l}\text { C 4) b) is there a licensing regime for internet } 1.0: \text { Yes } \\
\text { service providers? }\end{array}$ \\
\hline $\begin{array}{l}\text { DifferentForeign } \\
\text { Criteria }\end{array}$ & $\begin{array}{l}\text { C 4) d) are foreign firms subject to different } 1.0: \text { Yes } \\
\text { licensing criteria than domestic firms? }\end{array}$ \\
\hline Exclusivity & $\begin{array}{l}\text { C 4) e) Do licenses grant exclusivity periods in } 1.0: \text { Yes } \\
\text { all or some market segments? }\end{array}$ \\
\hline GatewaysOwn & $\begin{array}{l}\text { C 5) b) are service providers (beside 1.0: No } \\
\text { incumbents) allowed to own or lease their own 0.0: Yes } \\
\text { international data gateways? }\end{array}$ \\
\hline Tariffs & $\begin{array}{ll}\text { C 6) a) how are end-user tariffs determined? } & 0.0 \text { : if market forces alone } \\
\text { andC 6) b) are end-user tariffs set by } & 0.5 \text { : if a price cap is set by regulator, or } \\
& \text { regulator's approval is required } \\
& 1.0 \text { : if tariffs are set by regulator }\end{array}$ \\
\hline Transparency & $\begin{array}{l}\text { C 7) a) which of the following are consulted in } 1.0 \text { : not transparent } \\
\text { advance of regulatory decisions? } 0.0 \text { : very transparent } \\
\text { C 7) b) how are regulatory decisions and laws } \\
\text { made public? }\end{array}$ \\
\hline UniversalService & $\begin{array}{l}\text { D 2) what policy instruments are used to ensure } 0.0 \text { : Subsidies to operator, based on competitive } \\
\text { universal service? } \\
\text { D 4) How is the universal service provider } 0.2 \text { : Roll-out obligations included in licensing, } \\
\text { selected? } \\
\text { with subsidies } \\
\\
0.5: \text { roll-out obligations without subsidies } \\
1.0: \text { subsidies to operator, without competition } \\
\text { (for example only incumbent operator) }\end{array}$ \\
\hline
\end{tabular}




\section{Table A-2: Coding scheme for mobile telecom}

\begin{tabular}{lll}
\hline \multicolumn{1}{c}{ Variable Name } & \multicolumn{1}{c}{ Corresponding item(s) in the questionnaire } & \multicolumn{1}{c}{ Criteria for assigning value } \\
\hline MktEntryRestr & A 1) Are there policy restrictions on new entry ? By & 0.0 : No restriction \\
& any firm? & $1.0:$ strong restrictions in all segments \\
& & intermediate values depending on \\
& restrictions in segments
\end{tabular}
MktEntryRestrForeign A 1) Are there policy restrictions on new entry? By
foreign firms?
0.0 : No restriction

or (1.0 - maximum allowed foreign equity share)

1: If there are restrictions in all 3 sectors 0.67: for restrictions in 2 sectors 0.33 for restrictions in 1 sector 0.0 : No restrictions

\begin{tabular}{lll}
\hline PrivateOwn & B 1) is private ownership in the provision of services & $0.0:$ Yes \\
allowed? For existing operators? For new entrants? & $1.0:$ No \\
& & \\
\hline ForeignOwn & B 2) is foreign ownership in the provision of services & $(1$ - maximum allowed foreign equity \\
allowed? For existing operators? For new entrants? & share) \\
& & $1.0:$ Not allowed \\
\hline LicensingProcedure & C 3) a) What are the main criteria new entrants must & $0.1:$ license fee \\
& satisfy to be granted a license? & +0.1 competitive tender \\
& & $+0.2:$ economic needs test \\
& +0.1 submission of information \\
& +0.5 discretionary decision by authority
\end{tabular}

DifferentForeignCriteria $\mathrm{C}$ 3) b) are foreign firms subject to different licensing 0.0 : No criteria than domestic firms? 1.0 : No foregin firms allowed Intermediate values proportional to restrictions

\begin{tabular}{lll}
\hline Exclusivity & C 3) c) Do licenses grant an exclusivity period in all & 0.0 : No \\
& or some market segments? & $1.0:$ Yes
\end{tabular}

SeparateInternetLicense $\mathrm{C} 3$ ) e) is separate licensing required for provision of 0.0 : No internet connectivity through mobile services? $\quad 1.0$ : Yes

DifferentForeignInternet C 3) f) Are foreign firms subject to different internet 0.0 : No licensing criteria than domestic firms? $\quad 1.0$ : Yes (or not yet decided)

Variable Name Corresponding item(s) in the questionnaire Criteria for assigning value 


\begin{tabular}{|c|c|c|}
\hline Variable Name & Corresponding item(s) in the questionnaire & Criteria for assigning value \\
\hline TradeLicenses & C 4) b) can licenses be traded? & $\begin{array}{l}0.0: \text { Yes } \\
1.0: \text { No }\end{array}$ \\
\hline RegulationConstraints & $\begin{array}{l}\text { C 3) d) do licenses foresee specific roll-out plans? } \\
\text { C 5) b) which of the following are determined by the } \\
\text { regulator? }\end{array}$ & $\begin{array}{l}0.4 \text { if specific roll-out plan } \\
+0.1 \text { per item determined byt he regulator }\end{array}$ \\
\hline Tariffs & $\begin{array}{l}\text { C 6) a) How are end-user tariffs determined? } \\
\text { C 6) b) are end-user tariffs set by }\end{array}$ & $\begin{array}{l}0.0 \text { : if market forces alone } \\
0.5 \text { : if a price cap is set by regulator, or } \\
\text { regulator's approval is required } \\
1.0 \text { : if tariffs are set by regulator }\end{array}$ \\
\hline Transparency & $\begin{array}{l}\text { C 7) a) which of the following are consulted in } \\
\text { advance of regulatory decisions? } \\
\text { C 7) b) How are regulatory decisions and laws made } \\
\text { public? }\end{array}$ & $\begin{array}{l}\text { 1.0: not transparent } \\
0.0: \text { very transparent }\end{array}$ \\
\hline
\end{tabular}


Table A-3: Coding scheme for distribution

\begin{tabular}{|c|c|c|}
\hline Variable Name & Criteria for assigning value & \\
\hline FDI & $\begin{array}{l}\text { B 2) is foreign ownership in the provision of services allowed? For } \\
\text { existing operators? }\end{array}$ & $\begin{array}{r}\text { (1 - maximum } \\
\text { allowed } \\
\text { foreign equity } \\
\text { share) } \\
1.0 \text { : Not } \\
\text { allowed }\end{array}$ \\
\hline \multirow{4}{*}{$\begin{array}{l}\text { General factors } \\
\text { investments }\end{array}$} & affecting Local employment requirements & 0.8 \\
\hline & Only a few sectors allowed & 0.7 \\
\hline & Amount of capital invested and form of society & 0.4 \\
\hline & Single brand in retail but other way of doing multi brands & 0.2 \\
\hline \multirow[t]{4}{*}{ Trade activity } & Allowed & 0 \\
\hline & $\begin{array}{l}\text { Allowed to foreigners up to } 51 \% \text { or } 100 \% \text { FDI but only some } \\
\text { sectors }\end{array}$ & 0.5 \\
\hline & Trade controlled for domestic and foreing firms for many sectors & 0.7 \\
\hline & Not allowed to foreigners (imports in particular) & 1 \\
\hline \multirow[t]{5}{*}{ E commerce } & Allowed & 0 \\
\hline & Only a few products excluded & 0.2 \\
\hline & Only for certain categories (B2B) and paying a sum & 0.5 \\
\hline & Only up to a certain amount of money (2500 USD) & 0.7 \\
\hline & Not allowed at all & 1 \\
\hline
\end{tabular}

State Monopolies- Produc No monopolies 0

exclusions

Monopolies in some sectors/pdets

(oil, gas, tobacco, drugs, alcohol)

$\begin{array}{ll}\text { A few more sectors are monopolies } & 0.5\end{array}$

\begin{tabular}{|c|c|c|}
\hline & A lot of sectors are monopolies & 0.8 \\
\hline \multirow{5}{*}{$\begin{array}{l}\text { Transparency } \\
\text { deadline }\end{array}$} & statutory Not transparent at all & 0.5 \\
\hline & Not very transparent (only official) & 0.3 \\
\hline & Very transparent & 0 \\
\hline & No statutory deadline to approve & 0.5 \\
\hline & Clarity in statutory deadlines and very transparent & 0 \\
\hline $\begin{array}{l}\text { Factors affecting } \\
\text { establishment }\end{array}$ & $\begin{array}{l}\text { local A large number of administrative requirements } \\
\text { (the score is given by the number of required compliance when } \\
\text { opening a retail or a wholesale) }\end{array}$ & 0.5 \\
\hline
\end{tabular}




\begin{tabular}{|c|c|c|}
\hline \multirow[t]{3}{*}{ Variable Name } & \multicolumn{2}{|l|}{ Criteria for assigning value } \\
\hline & $\begin{array}{l}\text { Regulation in addition to urban planning, for some goods } \\
\text { (e.g. hazardous goods) }\end{array}$ & 0.2 \\
\hline & $\begin{array}{l}\text { Regulation in addition to urban planning, } \\
\text { for almost all goods }\end{array}$ & 0.5 \\
\hline \multirow[t]{3}{*}{$\begin{array}{l}\text { Other_factors } \\
\text { establish }\end{array}$} & $\begin{array}{l}\text { Restrictions on operating hours } \\
\text { ( } 0 \text { if no regulated or regulated but not restrictive) }\end{array}$ & 0.2 \\
\hline & $\begin{array}{l}\text { Control of prices } \\
\text { (half score if some few nb of pdcts but not many) }\end{array}$ & 0.4 \\
\hline & $\begin{array}{l}\text { Restriction on promoting initiatives } \\
\text { (promotion, discount, free gifts) }\end{array}$ & 0.4 \\
\hline \multirow[t]{5}{*}{ Restrictions on large scale stores } & Compliance with specific large outlets & 0.2 \\
\hline & Maximum total surface in an outlet & 0.2 \\
\hline & $\begin{array}{l}\text { Limitation or different treatment } \\
\text { Depending on the size }\end{array}$ & 0.2 \\
\hline & Special application form needed & 0.2 \\
\hline & Regulation required to expand & 0.2 \\
\hline \multirow[t]{2}{*}{ Wholesale import licensing } & Technical standards needed for RFID inventory & 0.3 \\
\hline & Zoning regulations stringent & 0.5 \\
\hline
\end{tabular}




\section{APPEndix B: SeCtOR DATASETS USED FOR REgRESSIONS}

Table B-1: Fixed telecom sector

\begin{tabular}{|c|c|c|c|}
\hline Variable & Description & Year & Source \\
\hline CAPINT0204 & $\begin{array}{l}\text { Capital intensity of production }=\text { Total capital } / \text { Net } \\
\text { Sales }\end{array}$ & $\begin{array}{l}2002- \\
2004 \\
\text { (average) }\end{array}$ & $\begin{array}{l}\text { Datastream and own } \\
\text { calculations }\end{array}$ \\
\hline \multirow[t]{2}{*}{ DSHARE0203 } & Percentage of digital mainlines & $\begin{array}{l}2002- \\
2003 \\
\text { (average) }\end{array}$ & $\begin{array}{l}\text { ITU World } \\
\text { Telecommunication } \\
\text { Indicators and own } \\
\text { calculations }\end{array}$ \\
\hline & Recent growth in industry revenue $=($ Industry revenue & $2002-$ & ITU World \\
\hline GREV0203 & 2003 - Industry revenue 2002) / Industry revenue 2002 & 2003 & $\begin{array}{l}\text { Telecommunication } \\
\text { Indicators and own } \\
\text { calculations }\end{array}$ \\
\hline GROWTH0204 & $\begin{array}{l}\text { Recent growth of firm sales }=(\text { Net Sales } 04-\text { Net } \\
\text { Sales02 }) / \text { Net Sales } 02\end{array}$ & $\begin{array}{l}2002- \\
2004\end{array}$ & $\begin{array}{l}\text { Datastream and own } \\
\text { calculations }\end{array}$ \\
\hline MFE & $\begin{array}{l}\text { Dummy variable }=1 \text { if a country has at least one MFN } \\
\text { exemption for the fixed-link telecommunications sector, } \\
\text { else } 0\end{array}$ & $\begin{array}{l}\text { GATS } \\
\text { schedules }\end{array}$ & $\begin{array}{l}\text { GATS and own } \\
\text { calculations }\end{array}$ \\
\hline MLINES0x03 & No. of mainlines & $\begin{array}{l}2002- \\
2003 \\
\text { (average) }\end{array}$ & $\begin{array}{l}\text { ITU World } \\
\text { Telecommunication } \\
\text { Indicators and own } \\
\text { calculations } \\
\end{array}$ \\
\hline MLINESPOP0203 & Teledensity $=$ No. of mainlines $/$ Population & $\begin{array}{l}2002- \\
2003 \\
\text { average }\end{array}$ & $\begin{array}{l}\text { ITU World } \\
\text { Telecommunication } \\
\text { Indicators and own } \\
\text { calculations }\end{array}$ \\
\hline PCM020x & Price-cost margin $=($ EBIT + Depreciation $) /$ Net Sales & $\begin{array}{l}2002- \\
2004 \\
\text { (average) }\end{array}$ & $\begin{array}{l}\text { Datastream and own } \\
\text { calculations }\end{array}$ \\
\hline RTA & $\begin{array}{l}\text { Dummy variable }=1 \text { if a country has signed at least one } \\
\text { RTA covering the fixed-line telecommunications } \\
\text { sector, else } 0\end{array}$ & $\begin{array}{l}2002- \\
2004\end{array}$ & GATS /RTAs \\
\hline SALESUSD0204 & Net Sales & $\begin{array}{l}2002- \\
2004 \\
\text { (average) }\end{array}$ & $\begin{array}{l}\text { Datastream and own } \\
\text { calculations }\end{array}$ \\
\hline SALESUSDEMP0204 & Labour productivity $=$ Net sales $/$ No. of employees & $\begin{array}{l}2002- \\
2004 \\
\text { (average) }\end{array}$ & $\begin{array}{l}\text { Datastream and own } \\
\text { calculations }\end{array}$ \\
\hline SHARE0204 & Market Share $=$ Net sales $/$ Total sector net sales & $\begin{array}{l}2002- \\
2004 \\
\text { (average) }\end{array}$ & $\begin{array}{l}\text { Datastream and own } \\
\text { calculations }\end{array}$ \\
\hline
\end{tabular}

Source: Dihel et al. (2007). 
Table B-2: Mobile telecom sector

\begin{tabular}{|c|c|c|c|}
\hline Variable & Description & Year & Source \\
\hline CAPINT0204 & $\begin{array}{l}\text { Capital intensity of production }=\text { Total capital } / \\
\text { Net Sales } \\
\text { Recent growth in industry revenue }=\text { (Industry }\end{array}$ & $\begin{array}{l}2002-2004 \\
\text { (average) }\end{array}$ & $\begin{array}{l}\text { Datastream and own } \\
\text { calculations }\end{array}$ \\
\hline GREV0203 & $\begin{array}{l}\text { revenue } 2003 \text { - Industry revenue 2002) / } \\
\text { Industry revenue } 2002\end{array}$ & $2002-2003$ & $\begin{array}{l}\text { ITU World } \\
\text { Telecommunication } \\
\text { Indicators and own } \\
\text { calculations }\end{array}$ \\
\hline GROWTH0204 & $\begin{array}{l}\text { Recent growth of firm sales }=(\text { Net Sales } 04- \\
\text { Net Sales02 }) / \text { Net Sales } 02 \\
\text { Dummy variable }=1 \text { if a country has at least one }\end{array}$ & $2002-2004$ & $\begin{array}{l}\text { Datastream and own } \\
\text { calculations }\end{array}$ \\
\hline MFE & $\begin{array}{l}\text { MFN exemption for the mobile } \\
\text { telecommunications sector, else } 0\end{array}$ & $\begin{array}{l}\text { GATS } \\
\text { schedules }\end{array}$ & $\begin{array}{l}\text { GATS } \\
\text { and own calculations }\end{array}$ \\
\hline SUBS0203 & No. of cellular phone subscribers & $\begin{array}{l}2002-2003 \\
\text { (average) }\end{array}$ & $\begin{array}{l}\text { ITU World } \\
\text { Telecommunication } \\
\text { Indicators and own } \\
\text { calculations }\end{array}$ \\
\hline SUBSPOP0203 & $\begin{array}{l}\text { Teledensity }=\text { No. of cellular phone subscribers } / \\
\text { Population }\end{array}$ & $\begin{array}{l}2002-2003 \\
\text { average }\end{array}$ & $\begin{array}{l}\text { ITU World } \\
\text { Telecommunication } \\
\text { Indicators and own } \\
\text { calculations } \\
\end{array}$ \\
\hline PCM0204 & Price-cost margin $=($ EBIT + Depreciation $) /$ Net Sales & $\begin{array}{l}\text { 2002-2004 } \\
\text { (average) }\end{array}$ & $\begin{array}{l}\text { Datastream and own } \\
\text { calculations }\end{array}$ \\
\hline RTA & $\begin{array}{l}\text { dummy variable }=1 \text { if a country has signed at } \\
\text { least one RTA covering the mobile } \\
\text { telecommunications sector, else } 0\end{array}$ & $2002-2004$ & GATS and RTAs \\
\hline SALESUSD0204 & Net Sales & $\begin{array}{l}2002-2004 \\
\text { (average) }\end{array}$ & $\begin{array}{l}\text { Datastream and own } \\
\text { calculations }\end{array}$ \\
\hline SALESUSDEMP0204 & Labour productivity $=$ Net sales $/$ No. Of employees & $\begin{array}{l}\text { 2002-2004 } \\
\text { (average) }\end{array}$ & $\begin{array}{l}\text { Datastream and own } \\
\text { calculations }\end{array}$ \\
\hline SHARE0204 & Market Share $=$ Net sales $/$ Total sector net sales & $\begin{array}{l}\text { 2002-2004 } \\
\text { (average) }\end{array}$ & $\begin{array}{l}\text { Datastream and own } \\
\text { calculations }\end{array}$ \\
\hline
\end{tabular}

Source: Dihel et al. (2007). 
Table B-3: Distribution sector

\begin{tabular}{|c|c|c|c|}
\hline Variable & Description & Year & Source \\
\hline CAPINT0204 & $\begin{array}{l}\text { Capital intensity of production }=\text { Total capital } / \text { Net } \\
\text { Sales }\end{array}$ & $\begin{array}{l}2002- \\
2004 \\
\text { (average) }\end{array}$ & $\begin{array}{l}\text { Datastream and } \\
\text { own calculations }\end{array}$ \\
\hline GIxDSALES0204 & $\begin{array}{l}\text { Recent growth in industry sales }=(\text { Industry net } \\
\text { sales } 03 \text { - Industry net sales } 02) / \text { Industry net } \\
\text { sales } 02\end{array}$ & $\begin{array}{l}2002- \\
2003 \\
\text { (average) }\end{array}$ & $\begin{array}{l}\text { Datastream and } \\
\text { own calculations }\end{array}$ \\
\hline GROWTH0204 & $\begin{array}{l}\text { Recent growth of firm sales }=(\text { Net Sales } 03-\text { Net } \\
\text { Sales02 }) / \text { Net Sales02 }\end{array}$ & $\begin{array}{l}2002- \\
2004 \\
\text { (average) }\end{array}$ & $\begin{array}{l}\text { Datastream and } \\
\text { own calculations }\end{array}$ \\
\hline INVSALES0204 & Efficiency of supply $=$ Total inventories $/$ Net sales & 2004 & $\begin{array}{l}\text { Datastream and } \\
\text { own calculations }\end{array}$ \\
\hline MFE & $\begin{array}{l}\text { Dummy variable }=1 \text { if a country has at least one } \\
\text { MFN exemption fox the distribution sector, else } 0\end{array}$ & $\begin{array}{l}\text { GATS } \\
\text { schedules }\end{array}$ & $\begin{array}{l}\text { GATS and } \\
\text { own calculations }\end{array}$ \\
\hline PCMAVE0204 & $\begin{array}{l}\text { Price-cost margin }=(\text { EBIT }+ \text { Depreciation }) / \text { Net } \\
\text { Sales }\end{array}$ & $\begin{array}{l}2002- \\
2004 \\
\text { (average) }\end{array}$ & $\begin{array}{l}\text { Datastream and } \\
\text { own calculations }\end{array}$ \\
\hline RTA & $\begin{array}{l}\text { Dummy variable }=1 \text { if a country has signed at least } \\
\text { one RTA covering the distribution sector, else } 0\end{array}$ & $\begin{array}{l}2002- \\
2004\end{array}$ & $\begin{array}{l}\text { GATS/RTAs } \\
\text { and own } \\
\text { calculations }\end{array}$ \\
\hline SALES0204 & Net sales & $\begin{array}{l}2002- \\
2004 \\
\text { (average) }\end{array}$ & $\begin{array}{l}\text { Datastream and } \\
\text { own calculations }\end{array}$ \\
\hline $\begin{array}{l}\text { SALESEMP0204 } \\
\text { (average) }\end{array}$ & Labour productivity $=$ Net sales $/$ No. of employees & $\begin{array}{l}2002- \\
2004 \\
\text { (average) }\end{array}$ & $\begin{array}{l}\text { Datastream and } \\
\text { own calculations }\end{array}$ \\
\hline SHARE0204 & Market Share $=$ Net Saxes $/$ Total sector net sales & 2004 & $\begin{array}{l}\text { Datastream and } \\
\text { own } \\
\text { calculations }\end{array}$ \\
\hline SOLV0204 & $\begin{array}{l}\text { Solvency ratio }=(\text { Total debt } /(\text { Total capital }+ \\
\text { short-term debt }))^{*} 100\end{array}$ & $\begin{array}{l}2002- \\
2004 \\
\text { (average) }\end{array}$ & $\begin{array}{l}\text { Datastream and } \\
\text { Own calculations }\end{array}$ \\
\hline
\end{tabular}

Source: Dihel et al. (2007). 


\section{APPENDIX C: ADDITIONAL RESULTS FOR REGRESSIONS}

Table C-1: Fixed telecom sector

\begin{tabular}{|c|c|c|c|c|c|c|}
\hline $\begin{array}{l}\text { Dep var : log firm level price- } \\
\text { cost margins }\end{array}$ & (1) & (2) & (3) & (4) & (5) & (6) \\
\hline Productivity & $\begin{array}{c}0.0286 \\
(0.0545)\end{array}$ & $\begin{array}{c}0.0555 \\
(0.0580)\end{array}$ & $\begin{array}{c}0.0602 \\
(0.0579)\end{array}$ & $\begin{array}{c}0.0292 \\
(0.0540)\end{array}$ & $\begin{array}{c}0.0539 \\
(0.0558)\end{array}$ & $\begin{array}{c}0.0679 \\
(0.0590)\end{array}$ \\
\hline Market share & $\begin{array}{c}0.0403 \\
(0.0301)\end{array}$ & $\begin{array}{c}0.0348 \\
(0.0334)\end{array}$ & $\begin{array}{c}0.0322 \\
(0.0335)\end{array}$ & $\begin{array}{c}0.0400 \\
(0.0294)\end{array}$ & $\begin{array}{c}0.0355 \\
(0.0324)\end{array}$ & $\begin{array}{c}0.0366 \\
(0.0326)\end{array}$ \\
\hline Sales growth & $\begin{array}{c}0.646^{* * *} \\
(0.214)\end{array}$ & $\begin{array}{l}0.541 * * * \\
(0.182)\end{array}$ & $\begin{array}{l}0.504 * * \\
(0.192)\end{array}$ & $\begin{array}{c}0.649 * * * \\
(0.212)\end{array}$ & $\begin{array}{c}0.536 * * * \\
(0.183)\end{array}$ & $\begin{array}{l}0.504 * * \\
(0.194)\end{array}$ \\
\hline Capital intensity & $\begin{array}{l}0.742 * * * \\
(0.0878)\end{array}$ & $\begin{array}{l}0.701 * * * \\
(0.0664)\end{array}$ & $\begin{array}{l}0.696 * * * \\
(0.0680)\end{array}$ & $\begin{array}{l}0.743 * * * \\
(0.0884)\end{array}$ & $\begin{array}{l}0.699 * * * \\
(0.0673)\end{array}$ & $\begin{array}{l}0.694 * * * \\
(0.0708)\end{array}$ \\
\hline TRI_1 & $\begin{array}{l}-0.0239 \\
(0.0576)\end{array}$ & $\begin{array}{l}-0.170 * * * \\
(0.0285)\end{array}$ & $\begin{array}{l}-0.168^{* * *} \\
(0.0296)\end{array}$ & & & \\
\hline TRI_1*RTA & & $\begin{array}{l}0.218 * * * \\
(0.0421)\end{array}$ & $\begin{array}{l}0.207 * * * \\
(0.0399)\end{array}$ & & & \\
\hline TRI_1*MFN & & & $\begin{array}{c}0.0849 \\
(0.0725)\end{array}$ & & & \\
\hline TRI_weighted & & & & $\begin{array}{l}-0.0456 \\
(0.110)\end{array}$ & $\begin{array}{l}-0.267 * * * \\
(0.0501)\end{array}$ & $\begin{array}{c}-0.254 * * * \\
(0.0493)\end{array}$ \\
\hline TRI_weighted*RTA & & & & & $\begin{array}{l}0.357 * * * \\
(0.0817)\end{array}$ & $\begin{array}{l}0.346^{* * *} \\
(0.0730)\end{array}$ \\
\hline TRI_weighted*MFN & & & & & & $\begin{array}{c}0.123 \\
(0.121)\end{array}$ \\
\hline Constant & $\begin{array}{c}-1.559 * * * \\
(0.325)\end{array}$ & $\begin{array}{c}-1.768 * * * \\
(0.358)\end{array}$ & $\begin{array}{c}-1.827 * * * \\
(0.356)\end{array}$ & $\begin{array}{c}-1.541 * * * \\
(0.341)\end{array}$ & $\begin{array}{c}-1.800 * * * \\
(0.349)\end{array}$ & $\begin{array}{c}-1.943 * * * \\
(0.357)\end{array}$ \\
\hline Observations & 69 & 69 & 69 & 69 & 69 & 69 \\
\hline R-squared & 0.525 & 0.564 & 0.568 & 0.525 & 0.564 & 0.569 \\
\hline $\begin{array}{l}\text { Robust standard errors in parent } \\
* * * \mathrm{p}<0.01, * * \mathrm{p}<0.05, * \mathrm{p}<0.1\end{array}$ & & & & & & \\
\hline
\end{tabular}




\section{Table C-2: Mobile telecom sector}

\begin{tabular}{|c|c|c|c|c|c|c|}
\hline $\begin{array}{l}\text { Dep var: log firm level } \\
\text { price-cost margins }\end{array}$ & (1) & (2) & (3) & (4) & (5) & (6) \\
\hline Productivity & $\begin{array}{c}0.164 \\
(0.118)\end{array}$ & $\begin{array}{c}0.138 \\
(0.107)\end{array}$ & $\begin{array}{c}0.137 \\
(0.105)\end{array}$ & $\begin{array}{c}0.187 \\
(0.110)\end{array}$ & $\begin{array}{c}0.150 \\
(0.101)\end{array}$ & $\begin{array}{c}0.147 \\
(0.0948)\end{array}$ \\
\hline Market share & $\begin{array}{c}0.0613^{* * *} \\
(0.0185)\end{array}$ & $\begin{array}{c}0.0517^{* * * *} \\
(0.0168)\end{array}$ & $\begin{array}{c}0.0497 * * * \\
(0.0169)\end{array}$ & $\begin{array}{c}0.0561^{* * *} \\
(0.0190)\end{array}$ & $\begin{array}{c}0.0432 * * * \\
(0.0142)\end{array}$ & $\begin{array}{c}0.0414^{* * *} \\
(0.0138)\end{array}$ \\
\hline Sales growth & $\begin{array}{c}0.445 \\
(0.281)\end{array}$ & $\begin{array}{c}0.176 \\
(0.190)\end{array}$ & $\begin{array}{c}0.190 \\
(0.204)\end{array}$ & $\begin{array}{c}0.460 \\
(0.285)\end{array}$ & $\begin{array}{c}0.174 \\
(0.179)\end{array}$ & $\begin{array}{l}0.178 \\
(0.186)\end{array}$ \\
\hline Capital intensity & $\begin{array}{l}0.738^{* * *} \\
(0.235)\end{array}$ & $\begin{array}{c}0.723 * * * \\
(0.229)\end{array}$ & $\begin{array}{c}0.724 * * * \\
(0.231)\end{array}$ & $\begin{array}{c}0.758^{* * *} \\
(0.226)\end{array}$ & $\begin{array}{l}0.745^{* * *} \\
(0.215)\end{array}$ & $\begin{array}{c}0.748^{* * *} \\
(0.222)\end{array}$ \\
\hline TRI_1 & $\begin{array}{l}-0.00372 \\
(0.0565)\end{array}$ & $\begin{array}{c}-0.193 * * * \\
(0.0441)\end{array}$ & $\begin{array}{c}-0.194 * * * \\
(0.0426)\end{array}$ & & & \\
\hline TRI_1*RTA & & $\begin{array}{l}0.254 * * * \\
(0.0451)\end{array}$ & $\begin{array}{l}0.260^{* * *} \\
(0.0379)\end{array}$ & & & \\
\hline TRI_1*MFN & & & $\begin{array}{l}-0.0379 \\
(0.0761)\end{array}$ & & & \\
\hline TRI_weighted & & & & $\begin{array}{l}0.0725 \\
(0.151)\end{array}$ & $\begin{array}{c}-0.307^{* * *} \\
(0.0973)\end{array}$ & $\begin{array}{c}-0.311^{* * *} \\
(0.0896)\end{array}$ \\
\hline TRI_weighted*RTA & & & & & $\begin{array}{l}0.586^{* * *} \\
(0.0917)\end{array}$ & $\begin{array}{l}0.594 * * * \\
(0.0813)\end{array}$ \\
\hline TRI_weighted*MFN & & & & & & $\begin{array}{l}-0.0294 \\
(0.116)\end{array}$ \\
\hline Constant & $\begin{array}{c}-2.353 * * * \\
(0.755)\end{array}$ & $\begin{array}{c}-2.245^{* * *} \\
(0.701)\end{array}$ & $\begin{array}{c}-2.229^{* * *} \\
(0.682)\end{array}$ & $\begin{array}{c}-2.589^{* * *} \\
(0.702)\end{array}$ & $\begin{array}{c}-2.565 * * * \\
(0.682)\end{array}$ & $\begin{array}{c}-2.538^{* * *} \\
(0.635)\end{array}$ \\
\hline Observations & 61 & 61 & 61 & 61 & 61 & 61 \\
\hline $\begin{array}{l}\text { R-squared } \\
\text { Robust standard errors in } \\
* * * \mathrm{p}<0.01, * * \mathrm{p}<0.05, *\end{array}$ & $\begin{array}{l}\quad 0.358 \\
\text { parentheses } \\
p<0.1\end{array}$ & 0.450 & 0.452 & 0.361 & 0.475 & 0.476 \\
\hline
\end{tabular}




\section{Table C-3: Distribution sector}

\begin{tabular}{|c|c|c|c|c|c|c|}
\hline & (1) & (2) & (3) & (4) & (5) & (6) \\
\hline Industry sales & $\begin{array}{c}-0.224 * * * \\
(0.0587)\end{array}$ & $\begin{array}{l}-0.0355 \\
(0.0834)\end{array}$ & $\begin{array}{l}-0.0672 \\
(0.0723)\end{array}$ & $\begin{array}{c}-0.271 * * * \\
(0.0663)\end{array}$ & $\begin{array}{c}-0.241 * * \\
(0.105)\end{array}$ & $\begin{array}{c}-0.220 * * \\
(0.101)\end{array}$ \\
\hline Sales growth & $\begin{array}{c}0.216^{* * *} \\
(0.0345)\end{array}$ & $\begin{array}{c}0.215 * * * \\
(0.0443)\end{array}$ & $\begin{array}{c}0.208 * * * \\
(0.0457)\end{array}$ & $\begin{array}{c}0.224 * * * \\
(0.0313)\end{array}$ & $\begin{array}{c}0.218^{* * *} \\
(0.0421)\end{array}$ & $\begin{array}{c}0.201 * * * \\
(0.0490)\end{array}$ \\
\hline Market share & $\begin{array}{c}0.0128 \\
(0.00943)\end{array}$ & $\begin{array}{c}0.0132 \\
(0.00790)\end{array}$ & $\begin{array}{c}0.0153 \\
(0.0120)\end{array}$ & $\begin{array}{c}0.0196 \\
(0.0118)\end{array}$ & $\begin{array}{l}0.0241^{*} \\
(0.0129)\end{array}$ & $\begin{array}{c}0.0249 * * \\
(0.0105)\end{array}$ \\
\hline Capital intensity & $\begin{array}{c}0.567 * * * \\
(0.0246)\end{array}$ & $\begin{array}{c}0.610 * * * \\
(0.0271)\end{array}$ & $\begin{array}{c}0.627 * * * \\
(0.0333)\end{array}$ & $\begin{array}{c}0.601 * * * \\
(0.0354)\end{array}$ & $\begin{array}{c}0.633 * * * \\
(0.0324)\end{array}$ & $\begin{array}{c}0.636^{* * *} \\
(0.0266)\end{array}$ \\
\hline Productivity & $\begin{array}{c}-0.224 * * * \\
(0.0530)\end{array}$ & $\begin{array}{c}-0.209 * * * \\
(0.0509)\end{array}$ & $\begin{array}{c}-0.178 * * * \\
(0.0465)\end{array}$ & $\begin{array}{c}-0.201 * * * \\
(0.0440)\end{array}$ & $\begin{array}{c}-0.181 * * * \\
(0.0433)\end{array}$ & $\begin{array}{c}-0.172 * * * \\
(0.0502)\end{array}$ \\
\hline Efficiency & $\begin{array}{l}-0.00342 \\
(0.0356)\end{array}$ & $\begin{array}{l}-0.00442 \\
(0.0292)\end{array}$ & $\begin{array}{l}-0.0135 \\
(0.0290)\end{array}$ & $\begin{array}{l}-0.0157 \\
(0.0314)\end{array}$ & $\begin{array}{l}-0.0158 \\
(0.0286)\end{array}$ & $\begin{array}{l}0.00545 \\
(0.0274)\end{array}$ \\
\hline Solvency & $\begin{array}{c}-0.0386 \\
(0.0241)\end{array}$ & $\begin{array}{l}-0.0363 \\
(0.0225)\end{array}$ & $\begin{array}{l}-0.0321 \\
(0.0228)\end{array}$ & $\begin{array}{c}-0.0242 \\
(0.0256)\end{array}$ & $\begin{array}{l}-0.0334 \\
(0.0220)\end{array}$ & \\
\hline TRI_1 & $\begin{array}{c}-0.0912 * * \\
(0.0352)\end{array}$ & $\begin{array}{c}-0.142 * * * \\
(0.0354)\end{array}$ & $\begin{array}{c}-0.138 * * * \\
(0.0334)\end{array}$ & & & \\
\hline TRI_1*RTA & & $\begin{array}{c}0.126 * * * \\
(0.0367)\end{array}$ & $\begin{array}{c}0.0781 * * * \\
(0.0269)\end{array}$ & & & \\
\hline TRI_1*MFE & & & $\begin{array}{l}0.0623 * \\
(0.0348)\end{array}$ & & & \\
\hline TRI_weighted & & & & $\begin{array}{c}-0.208 * * * \\
(0.0539)\end{array}$ & $\begin{array}{c}-0.235 * * * \\
(0.0398)\end{array}$ & $\begin{array}{c}-0.245 * * * \\
(0.0378)\end{array}$ \\
\hline TRI_weighted*RTA & & & & & $\begin{array}{l}-0.0147 \\
(0.0633)\end{array}$ & $\begin{array}{c}-0.000719 \\
(0.0591)\end{array}$ \\
\hline TRI_weighted*MFN & & & & & & $\begin{array}{c}0.0258 \\
(0.0524)\end{array}$ \\
\hline Constant & $\begin{array}{c}-0.630 * * \\
(0.275)\end{array}$ & $\begin{array}{l}-0.471 \\
(0.299)\end{array}$ & $\begin{array}{c}-0.676^{* * *} \\
(0.234)\end{array}$ & $\begin{array}{c}-0.775^{* * *} \\
(0.212)\end{array}$ & $\begin{array}{c}-0.693 * * * \\
(0.208)\end{array}$ & $\begin{array}{c}-0.776^{* * *} \\
(0.252)\end{array}$ \\
\hline Observations & 376 & 351 & 351 & 376 & 351 & 381 \\
\hline $\begin{array}{l}\text { R-squared } \\
\text { Robust standard errors in } \\
\text { parentheses } \\
* * * \mathrm{p}<0.01, * * \mathrm{p}<0.05, * \\
\mathrm{p}<0.1\end{array}$ & 0.512 & 0.594 & 0.599 & 0.524 & 0.605 & 0.581 \\
\hline
\end{tabular}


APPENDIX D: ADDITIONAL RESULTS FOR TARIFF EQUIVALENTS

Table D-1: Fixed telecom sector

\begin{tabular}{lccccc}
\hline & $(1)$ & + sigma** & -sigma** & $(2)$ & $(3)$ \\
\hline Argentina & 0.0 & 0.0 & 0.0 & 0.0 & 0.0 \\
Singapore & 6.1 & 5.1 & 7.0 & -1.3 & -7.8 \\
Brazil & 12.2 & 10.2 & 14.2 & -2.6 & -14.7 \\
Tunisia & 20.1 & 16.7 & 23.5 & -4.0 & -22.4 \\
Morocco & 40.2 & 33.1 & 47.8 & -7.3 & -37.3 \\
Indonesia & 46.2 & 37.9 & 55.0 & -8.2 & -40.8 \\
India & 46.2 & 37.9 & 55.1 & -8.2 & -40.9 \\
Egypt & 48.1 & 39.4 & 57.4 & -8.5 & -41.9 \\
Philippines & 54.1 & 44.1 & 64.7 & -9.3 & -45.0 \\
Malaysia & 77.4 & 62.4 & 93.9 & -12.1 & -54.7 \\
Thailand & 95.7 & 76.4 & 117.1 & -14.0 & -60.5 \\
\hline
\end{tabular}

Note:

(1): AVE of regulations applied to countries with whom there is no an RTA

(2): Regulatory preferential margin for countries with whom there is an RTA

(3): Sum of regulatory preferential margin and rent of MFN exemption

**: the tariff equivalent is calculated adding and subtracting to $\beta$ the value of $\sigma$

Table D-2: Mobile telecom sector

\begin{tabular}{lccccc}
\hline & $(1)$ & + sigma $^{* *}$ & - sigma** & $(2)$ & $(3)$ \\
\hline Argentina & 0 & 0 & 0 & 0 & $\mathrm{~ns}$ \\
Brazil & 11.9 & 7.8 & 16.1 & -5.9 & $\mathrm{~ns}$ \\
Singapore & 13.3 & 8.7 & 18.1 & -6.5 & $\mathrm{~ns}$ \\
India & 14.0 & 9.1 & 19.1 & -6.8 & $\mathrm{~ns}$ \\
Malaysia & 15.3 & 9.9 & 20.8 & -7.4 & $\mathrm{~ns}$ \\
Morocco & 15.7 & 10.2 & 21.4 & -7.6 & $\mathrm{~ns}$ \\
Philippines & 16.5 & 10.7 & 22.5 & -7.9 & $\mathrm{~ns}$ \\
Egypt & 18.0 & 11.7 & 24.7 & -8.6 & $\mathrm{~ns}$ \\
Tunisia & 21.5 & 13.9 & 29.7 & -10.0 & $\mathrm{~ns}$ \\
Thailand & 28.5 & 18.2 & 39.6 & -12.7 & $\mathrm{Ns}$ \\
Indonesia & 40.0 & 25.1 & 56.6 & -16.6 & $\mathrm{Ns}$ \\
\hline
\end{tabular}

Note:

(1): Av. of regulations applied to countries where there is no RTA

(2): Regulatory preferential margin for countries with which there is an $R T \quad A$

(3): Sum of regulatory preferential margin and rent from MFN exemption

**: the tariff equivalent is calculated adding and subtracting to $\beta$ the value of $\sigma$ 
Table D-3: Distribution sector

\begin{tabular}{lccccl}
\hline & $(1)$ & + sigma** & - sigma** & $(2)$ & $(3)$ \\
\hline Singapore & 0.0 & 0.0 & 0.0 & 0.0 & $\mathrm{~ns}$ \\
Argentina & 2.3 & 1.8 & 2.8 & -1.1 & $\mathrm{~ns}$ \\
Brazil & 3.8 & 3.0 & 4.5 & -1.8 & $\mathrm{~ns}$ \\
Morocco & 25.7 & 20.1 & 31.7 & -10.4 & $\mathrm{~ns}$ \\
Malaysia & 30.1 & 23.4 & 37.1 & -11.8 & $\mathrm{~ns}$ \\
Philippines & 42.2 & 32.5 & 52.6 & -15.5 & $\mathrm{~ns}$ \\
India & 43.8 & 33.7 & 54.8 & -16.0 & $\mathrm{~ns}$ \\
Egypt & 46.0 & 35.3 & 57.5 & -16.6 & $\mathrm{~ns}$ \\
Indonesia & 49.2 & 37.6 & 61.7 & -17.5 & $\mathrm{~ns}$ \\
Tunisia & 64.6 & 48.9 & 81.9 & -21.3 & $\mathrm{~ns}$ \\
Thailand & - & - & - & - & - \\
\hline
\end{tabular}

Note:

(1): Av. of regulations applied to countries where there is no RTA

(2): Regulatory preferential margin for countries with which there is an RTA

(3): Sum of regulatory preferential margin and rent from $M F N$ exemption

**: the tariff equivalent is calculated adding and subtracting to $\beta$ the value of $\sigma$ 


\section{LIST OF WORKING PAPERS RELEASED BY CEPII}

An Exhaustive list is available on the website: Ilwww.cepii.fr.

To receive an alert, please contact Sylvie Hurion (sylvie.hurion@cepii.fr).

No

2009-36 Les impacts économiques du changement climatique : enjeux de modélisation

2009-35 Trade, Foreign Inputs and Firms' Decisions: Theory and Evidence

2009-34 Export Sophistication and Economic Performance: Evidence from Chinese Provinces

2009-33 Assessing the Sustainability of Credit Growth: The Case of Central and Eastern European Countries

2009-32 How do different exporters react to exchange rate changes? Theory, empirics and aggregate implications

2009-31 Spillovers from Multinationals to Heterogeneous Domestic Firms: Evidence from Hungary

2009-30 Ethnic Networks, Information, and International Trade: Revisiting the Evidence

2009-29 Financial Constraints in China : Firm-level Evidence

2009-28 The Crisis: Policy Lessons and Policy Challenges

2009-27 Commerce et flux financiers internationaux : MIRAGE-D

2009-26 Oil Prices, Geography and Endogenous Regionalism: Too Much Ado about (Almost) Nothing

2009-25 EU15 Trade with Emerging Economies and Rentier States: Leveraging Geography

2009-24 Market Potential and Development

2009-23 Immigration, Income and Productivity of Host Countries: A Channel Accounting Approach

2009-22 A Picture of Tariff Protection Across the World in 2004 MAcMap-HS6, Version 2
Authors

P. Besson \& N. Kousnetzoff

M. Bas

J. Jarreau \& S. Poncet

V. Coudert \& C. Pouvelle

N. Berman, P. Martin \& Thierry Mayer

G. Békés, J. Kleinert \& F. Toubal

G. J. Felbermayr, B. Jung \& F. Toubal

S. Poncet, W. Steingress \& H. Vandenbussche

A. Bénassy-Quéré, B. Coeuré, P. Jacquet $\& J$. Pisani-Ferry

A. Lemelin

D. Mirza \& H. Zitouna

G. Gaulier, F. Lemoine \& D. Ünal

T. Mayer

A. Mariya \& A. Tritah

H. Boumellassa, D. Laborde Debucquet \& C. Mitaritonna 
No

Tittle

2009-21 Spatial Price Discrimination in International Markets

2009-20 Is Russia Sick with the Dutch Disease

2009-19 Économies d'agglomération à l'exportation et difficulté d'accès aux marchés

2009-18 Local Export Spillovers in France

2009-17 Currency Misalignments and Growth: A New Look using Nonlinear Panel Data Methods,

2009-16 Trade Impact of European Measures on GMOs Condemned by the WTO Panel

2009-15 Economic Crisis and Global Supply Chains

2009-14 Quality Sorting and Trade: Firm-level Evidence for French Wine

2009-13 New Evidence on the Effectiveness of Europe's Fiscal Restrictions

2009-12 Remittances, Capital Flows and Financial Development during the Mass Migration Period, 1870-1913

2009-11 Evolution of EU and its Member States'Competitiveness in International Trade

2009-10 Exchange-Rate Misalignments in Duopoly: The Case of Airbus and Boeing

2009-09 Market Positioning of Varieties in World Trade: Is Latin America Losing out on Asia?

2009-08 The Dollar in the Turmoil

2009-07 Term of Trade Shocks in a Monetary Union: An Application to West-Africa

2009-06 Macroeconomic Consequences of Global Endogenous Migration: A General Equilibrium Analysis

2009-05 Équivalence entre taxation et permis d'émission échangeables

\section{Authors}

J. Martin

V. Dobrynskaya \& E. Turkisch

P. Koenig, F. Mayneris $\&$ S. Poncet

P. Koenig, F. Mayneris \& S. Poncet

S. Béreau,

A. López Villavicencio \& V. Mignon

A. C. Disdier \& L. Fontagné

A. Bénassy-Quéré, Y. Decreux, L. Fontagné \& D. Khoudour-Casteras

M. Crozet, K. Head $\&$ T. Mayer

M. Poplawski Ribeiro

R. Esteves \& D. Khoudour-Castéras

L. Curran \& S. Zignago

A. Bénassy-Quéré, L. Fontagné \& H. Raff

N. Mulder, R. Paillacar \& S. Zignago

A Bénassy-Quéré, S. Béreau \& V. Mignon

L. Batté, A. Bénassy-Quéré, B. Carton \& G. Dufrénot V. Borgy, X. Chojnicki, G. Le Garrec \& C. Schwellnus P. Villa 
No

2009-04 The Trade-Growth Nexus in the Developing Countries: a Quantile Regression Approach

2009-03 Price Convergence in the European Union: within Firms or Composition of Firms?

2009-02 Productivité du travail : les divergences entre pays développés sont-elles durables?

2009-01 From Various Degrees of Trade to Various Degrees of Financial Integration: What Do Interest Rates Have to Say

2008-32 Do Terms of Trade Drive Real Exchange Rates? Comparing Oil and Commodity Currencies

2008-31 Vietnam's Accession to the WTO: Ex-Post Evaluation in a Dynamic Perspective

2008-30 Structural Gravity Equations with Intensive and Extensive Margins

2008-29 Trade Prices and the Euro

2008-28 Commerce international et transports : tendances du passé et prospective 2020

2008-27 The Erosion of Colonial Trade Linkages after Independence

2008-26 Plus grandes, plus fortes, plus loin... Performances relatives des firmes exportatrices françaises

2008-25 A General Equilibrium Evaluation of the Sustainability of the New Pension Reforms in Italy

2008-24 The Location of Japanese MNC Affiliates:

Agglomeration, Spillovers and Firm Heterogeneity

2008-23 Non Linear Adjustment of the Real Exchange Rate

Towards its Equilibrium Values

2008-22 Demographic Uncertainty in Europe - Implications on

Macro Economic Trends and Pension Reforms - An

Investigation with the INGENUE2 Model

2008-21 The Euro Effects on the Firm and Product-Level Trade Margins: Evidence from France

2008-20 The Impact of Economic Geography on Wages:

Disentangling the Channels of Influence

\section{Authors}

G. Dufrénot, V. Mignon \&

C. Tsangarides

I. Méjean

\& C. Schwellnus

C. Bosquet \& M. Fouquin

A. Bachellerie, J. Héricourt \& V. Mignon

V. Coudert, C. Couharde \& V. Mignon

H. Boumellassa \& H. Valin

M. Crozet \& P. Koenig

J. Martin \& I. Méjean

C. Gouel, N. Kousnetzoff \& H. Salman

T. Mayer, K. Head \& J. Ries

M. Crozet, I. Méjean \& S. Zignago

R. Magnani

T. Inui, T. Matsuura \& S. Poncet

S. Béreau,

A. Lopez Villavicencio \& V. Mignon

M. Aglietta \& V. Borgy

A. Berthou \& L. Fontagné

L. Hering \& S. Poncet 
No

Tittle

2008-19 Do Corporate Taxes Reduce Productivity and Investment at the Firm Level? Cross-Country Evidence from the Amadeus Dataset

2008-18 Choosing Sensitive Agricultural Products in Trade Negotiations

2008-17 Government Consumption Volatility and Country Size

2008-16 Inherited or Earned? Performance of Foreign Banks in Central and Eastern Europe

2008-15 The Effect of Foreign Bank Entry on the Cost of Credit in Transition Economies. Which Borrowers Benefit most?

2008-14 Contagion in the Credit Default Swap Market: the Case of the GM and Ford Crisis in 2005.

2008-13 Exporting to Insecure Markets: A Firm-Level Analysis

2008-12 Social Competition and Firms' Location Choices

2008-11 Border Effects of Brazilian States

2008-10 International Trade Price Indices

2008-09 Base de données CHELEM - Commerce international du CEPII

2008-08 The Brain Drain between Knowledge Based Economies: the European Human Capital Outflows to the US

2008-07 Currency Misalignments and Exchange Rate Regimes in Emerging and Developing Countries

2008-06 The Euro and the Intensive and Extensive Margins of Trade: Evidence from French Firm Level Data

2008-05 On the Influence of Oil Prices on Economic Activity and other Macroeconomic and Financial Variables

2008-04 An Impact Study of the EU-ACP Economic Partnership Agreements (EPAs) in the Six ACP Regions

2008-03 The Brave New World of Cross-Regionalism

2008-02 Equilibrium Exchange Rates: a Guidebook for the EuroDollar Rate

\section{Authors}

J. Arnold

\& C. Schwellnus

S. Jean, D. Laborde \& W. Martin

D. Furceri

\& M. Poplawski Ribeiro

O. Havrylchyk \& E. Jurzyk

H. Degryse,

O. Havrylchyk, E. Jurzyk \& S. Kozak

V. Coudert \& M. Gex

M. Crozet, P. Koenig \& V. Rebeyrol

V. Delbecque, I. Méjean \& L. Patureau

M. Daumal \& S. Zignago

G. Gaulier, J. Martin, I. Méjean \& S. Zignago

A. de Saint Vaulry

A. Tritah

V. Coudert\& C. Couharde

A. Berthou \& L. Fontagné

F. Lescaroux\& V. Mignon

L. Fontagné, D. Laborde \& C. Mitaritonna

A. Tovias

A. Bénassy-Quéré, S. Béreau \& V. Mignon 
CEPII, WP No 2009-37 Assessing Barriers to Trade in the Distribution and Telecom sectors in Emerging Countries

No

2008-01
Tittle

How Robust are Estimated Equilibrium Exchange Rates?

A Panel BEER Approach
Authors

A. Bénassy-Quéré, S. Béreau \& V. Mignon 
Organisme public d'étude et de recherche en économie internationale, le CEPII est placé auprès du Centre d'Analyse Stratégique. Son programme de travail est fixé par un conseil composé de responsables de l'administration et de personnalités issues des entreprises, des organisations syndicales et de l'Université.

Les documents de travail du CEPII mettent à disposition du public professionnel des travaux effectués au CEPII, dans leur phase d'élaboration et de discussion avant publication définitive. Les documents de travail sont publiés sous la responsabilité de la direction du CEPII et n'engagent ni le conseil du Centre, ni le Centre d'Analyse Stratégique. Les opinions qui y sont exprimées sont celles des auteurs.

Les documents de travail du CEPII sont disponibles sur le site : http//www.cepii.fr.

CEPII

9, RUe Georges Pitard, 75740 Paris Cedex 15

SYLVIE HURION - PUbliCATIONS

TÉL : 0153685514 - FAX : 0153685504

sylvie.hurion@cepii.fr

ISSN : 1293-2574 